\title{
The effects of global change upon United States air quality
}

\author{
R. Gonzalez-Abraham ${ }^{1, a}$, S. H. Chung ${ }^{1}$, J. Avise ${ }^{1,2}$, B. Lamb ${ }^{1}$, E. P. Salathé Jr. ${ }^{3}$, C. G. Nolte ${ }^{4}$, D. Loughlin ${ }^{4}$, \\ A. Guenther ${ }^{5, b}$, C. Wiedinmyer ${ }^{5}$, T. Duhl ${ }^{5}$, Y. Zhang ${ }^{5}$, and D. G. Streets ${ }^{6}$ \\ ${ }^{1}$ Washington State University, Pullman, Washington, USA \\ ${ }^{2}$ California Air Resources Board, Sacramento, California, USA \\ ${ }^{3}$ University of Washington-Bothel, Bothel, Washington, USA \\ ${ }^{4}$ Environmental Protection Agency, Research Triangle Park, North Carolina, USA \\ ${ }^{5}$ National Center for Atmospheric Research, Boulder, Colorado, USA \\ ${ }^{6}$ Argonne National Laboratory, Argonne, Illinois, USA \\ a now at: Portland State University, Portland, Oregon USA \\ ${ }^{b}$ now at: University of California-Irivine, Irvine, California, USA
}

Correspondence to: R. Gonzalez-Abraham (arodrigo@pdx.edu)

Received: 13 August 2014 - Published in Atmos. Chem. Phys. Discuss.: 17 December 2014

Revised: 15 August 2015 - Accepted: 25 September 2015 - Published: 13 November 2015

\begin{abstract}
To understand more fully the effects of global changes on ambient concentrations of ozone and particulate matter with aerodynamic diameter smaller than $2.5 \mu \mathrm{m}$ $\left(\mathrm{PM}_{2.5}\right)$ in the United States (US), we conducted a comprehensive modeling effort to evaluate explicitly the effects of changes in climate, biogenic emissions, land use and global/regional anthropogenic emissions on ozone and $\mathrm{PM}_{2.5}$ concentrations and composition. Results from the ECHAM5 global climate model driven with the A1B emission scenario from the Intergovernmental Panel on Climate Change (IPCC) were downscaled using the Weather Research and Forecasting (WRF) model to provide regional meteorological fields. We developed air quality simulations using the Community Multiscale Air Quality Model (CMAQ) chemical transport model for two nested domains with 220 and $36 \mathrm{~km}$ horizontal grid cell resolution for a semi-hemispheric domain and a continental United States (US) domain, respectively. The semihemispheric domain was used to evaluate the impact of projected global emissions changes on US air quality. WRF meteorological fields were used to calculate current (2000s) and future (2050s) biogenic emissions using the Model of Emissions of Gases and Aerosols from Nature (MEGAN). For the semi-hemispheric domain CMAQ simulations, presentday global emissions inventories were used and projected to the 2050s based on the IPCC A1B scenario. Regional anthropogenic emissions were obtained from the US Environmental Protection Agency National Emission Inventory 2002
\end{abstract}

(EPA NEI2002) and projected to the future using the MARKet ALlocation (MARKAL) energy system model assuming a business as usual scenario that extends current decade emission regulations through 2050. Our results suggest that daily maximum $8 \mathrm{~h}$ average ozone (DM8O) concentrations will increase in a range between 2 to 12 parts per billion (ppb) across most of the continental US. The highest increase occurs in the South, Central and Midwest regions of the US due to increases in temperature, enhanced biogenic emissions and changes in land use. The model predicts an average increase of $1-6 \mathrm{ppb}$ in DM8O due to projected increase in global emissions of ozone precursors. The effects of these factors are only partially offset by reductions in DM8O associated with decreasing US anthropogenic emissions. Increases in $\mathrm{PM}_{2.5}$ levels between 4 and $10 \mu \mathrm{g} \mathrm{m}^{-3}$ in the Northeast, Southeast, Midwest and South regions are mostly a result of increase in primary anthropogenic particulate matter (PM), enhanced biogenic emissions and land use changes. Changes in boundary conditions shift the composition but do not alter overall simulated $\mathrm{PM}_{2.5}$ mass concentrations. 


\section{Introduction}

Despite extensive efforts to reduce anthropogenic emissions, air pollution continues to be a public health issue in the United States (US EPA, 2010). Elevated concentrations of pollutants in the troposphere, such as ozone $\left(\mathrm{O}_{3}\right)$ and particulate matter, degrade air quality and have been associated with, among other things, increasing human respiratory diseases in urban areas (WHO, 2005), and in the case of particulate matter (PM), with low birth weights across the world (Dadvand et al., 2012).

High concentrations of tropospheric $\mathrm{O}_{3}$ and $\mathrm{PM}$ matter with aerodynamic diameter smaller than $2.5 \mu \mathrm{m}\left(\mathrm{PM}_{2.5}\right)$ are caused by a combination of adverse meteorological conditions and the atmospheric emissions of their primary precursors. While regulatory controls are expected to reduce emissions of many emitted pollutants in the United States (US) in the future, the negative effects of global climate change may offset the positive effects of such reductions. Furthermore, global emissions of greenhouse gases and other pollutant precursors are projected to increase (IPCC, 2007). Moreover, recent research has provided evidence of increasing long-range transport of $\mathrm{O}_{3}$ and $\mathrm{PM}_{2.5}$ precursors from Asia and their influence over the western US (Lelieveld and Dentener, 2009; Wuebbles et al., 2007; Cooper et al., 2010, 2012; Zhang et al., 2010; Ambrose et al., 2011; WMO, 2012; Lin et al., 2012).

In the United States, regulations and technological changes in the transportation and energy sectors are projected to reduce regional atmospheric pollutants in the future (Loughlin et al., 2011). However, the interplay between climate change, increasing global emissions, and intercontinental transport pose challenges that air quality managers will have to address in order to maintain regional air quality standards (Ravishankara et al., 2012). To provide a foundation for building effective management strategies and public policies in a changing global environment, modeling approaches that link global changes with regional air quality are required. The general approach has been to use output from general circulation models (GCMs) to drive regional climate models (RCMs) and regional or global chemical transport models (CTMs/GTMs; Giorgi and Meleux, 2007; Jacob and Winner, 2009).

This downscaling approach has been used in a variety of studies in Europe, Canada and Asia at different timescales of climate change - e.g., Liao et al., 2006 (2000 to 2100); Langner et al., 2005 (2000 to 2060); Forkel and Knoche, 2006 (2990 to 2030); Meleux et al., 2007 (1975 to 1985); Kunkel et al., 2007 (1990 to 2090); Lin et al., 2008 (2000 to 2100); Spracklen et al., 2009 (2000 to 2050); Kelly et al., 2012 (2000s to 2050s). These investigations based the global emissions on future anthropogenic emissions scenarios developed from the Intergovernmental Panel on Climate Change (IPCC) assessment reports. Despite the differences in emission scenarios, timescales, modeling frameworks and future climate realizations, increases in ozone concentrations on the order of 2 to 10 parts per billion (ppb) in polluted regions were consistently predicted from these studies as a result of climate change alone. By contrast, there is little consistency among the model predictions of climate change effects on PM (Jacob et al., 2009; Dawson et al., 2013).

In the US, a combined effort between the Environmental Protection Agency and the academic community resulted in a set of modeling studies that adopted a variety of modeling methods (Hogrefe et al., 2004; Leung and Gustafson, 2005; Liang et al., 2006; Steiner et al., 2006; Tagaris et al., 2007; Liao et al., 2006; Racherla and Adams, 2006, 2008; Tao et al., 2007; Huang et al., 2007, 2008; Nolte et al., 2008; Wu et al., 2008a, b; Chen et al., 2009b; Avise et al., 2009; Dawson et al., 2009). These US investigations based their current and future climate realizations on the results of GCMs using the various IPCC emissions scenarios (IPCC, 2007) projected to the 2050s. In some of the studies, the global climate realizations were subsequently downscaled to a higher resolution using the PSU (Pennsylvania State University)/NCAR (National Center for Atmospheric Research) Mesoscale Model version 5 (MM5; Grell et al., 1994) to horizontal resolutions that ranged from 90 to $36 \mathrm{~km}$. Many of these studies based their analysis on the effects of climate change on summer air quality in the continental US (CONUS). In summary, despite the differences in modeling elements, all studies found increases in the summer average of the daily maximum $8 \mathrm{~h}$ average ozone concentrations over large regions of CONUS on the order of 2 to $8 \mathrm{ppb}$ (Weaver et al., 2009). In contrast, PM concentrations showed changes between \pm 0.1 and $\pm 1 \mu \mathrm{g} \mathrm{m}^{-3}$, with little consistency between studies, including the sign of the differences (Day and Pandis, 2015; Trail et al., 2015; Jacob and Winner, 2009).

It is important to note that variations between modeling frameworks did result in very diverse regional patterns of key weather drivers for ozone and PM formation. Thus, while most of the studies mentioned above projected an average increase in ozone concentrations for the simulated domains, reductions or insignificant changes in certain regions of the domain were also simulated. Generally, temperature and solar radiation reaching the surface were the major meteorological drivers for regional ozone concentrations. For PM concentrations, most of the studies found a direct link between changes in precipitation and relative humidity and changes in PM concentrations (Liao et al., 2006; Unger et al., 2006; Racherla and Adams 2006; Tagaris et al., 2007; Avise et al., 2009; Chen et al., 2009b). Nevertheless, the direct impacts of changes in meteorological conditions are not the only factors of change for ozone and PM concentrations. Changes in emissions of biogenic volatile organic compounds (BVOCs), due to climate and land cover change, and the treatment of isoprene nitrates in the chemical mechanism were found to be a key factor in the regional variability of ozone and PM, particularly in areas of the southeastern US (Jacob and Winner, 2009; Weaver et al., 2009). 
In this work, we present a continuation of the work described by Avise et al. (2009) and Chen et al. (2009a, b), who downscaled the Parallel Climate Model (PCM; Washington et al., 2000) and MOZART (Model for OZone And Related chemical Tracers; Horowitz, 2006) global model output for the A2 IPCC scenario using MM5 and the Community Multiscale Air Quality Model (CMAQ; Byun and Schere, 2006) to simulate current and future air quality in the US. For this update, we implemented a semi-hemispheric domain for the Weather Research and Forecasting (WRF) mesoscale meteorological model (http://www.wrf-model.org) and CMAQ simulations in lieu of using MOZART output for chemical boundary conditions for our CONUS CMAQ simulations. We used the ECHAM5 global climate model (Roeckner et al., 1999, 2003) output for the A1B scenario to drive these simulations for 2 decadal periods: the current decade 1995-2004 and the future decade 2045-2054. In presenting our results, we follow the attribution approach described in Avise et al. (2009), where the separate and combined effects of changes in climate, US anthropogenic emissions, global anthropogenic emissions and biogenic emissions due to changes in regional meteorology and land use are investigated. Ideally, this framework should include feedback from changes in atmospheric chemistry to the climate system (Raes et al., 2010). However, due to the computational requirements of an online approach, we did not incorporate feedback between the atmospheric chemistry and transport simulations from the CTM to the RCM. Furthermore, despite the observed sensitivity of tropospheric ozone to regional emissions and global burden of methane (Zhang et al., 2011; Fiore et al., 2008; Wu et al., 2008a; Nolte et al., 2008), in this work, we do not address the direct effect of emissions of methane on the air quality simulations.

In Sect. 2, we provide an overview of the modeling framework and emissions scenarios. Evaluation of the model performance for the climate simulations and results of the changes in meteorological fields are also presented in Sect. 2. Assessment of air quality changes and the individual and combined effects from changes in model components are presented in Sect. 3. Finally, we present a summary of the results and conclusions in Sect. 4.

\section{Methodology}

\subsection{General framework}

Results from the global climate model ECHAM5 under the IPCC Special Report on Emissions Scenarios (SRES) A1B scenario (Nakicenovic et al., 2000) were downscaled using the WRF model separately to a semi-hemispheric (S-HEM) $220 \mathrm{~km}$ domain and nested CONUS domains of $108 \mathrm{~km}$ (not shown) and $36 \mathrm{~km}$ (Fig. 1). Although, it has been suggested that periods of 10 to 30 years are required to fully determine climatological conditions (Andersson and Engardt, 2010),

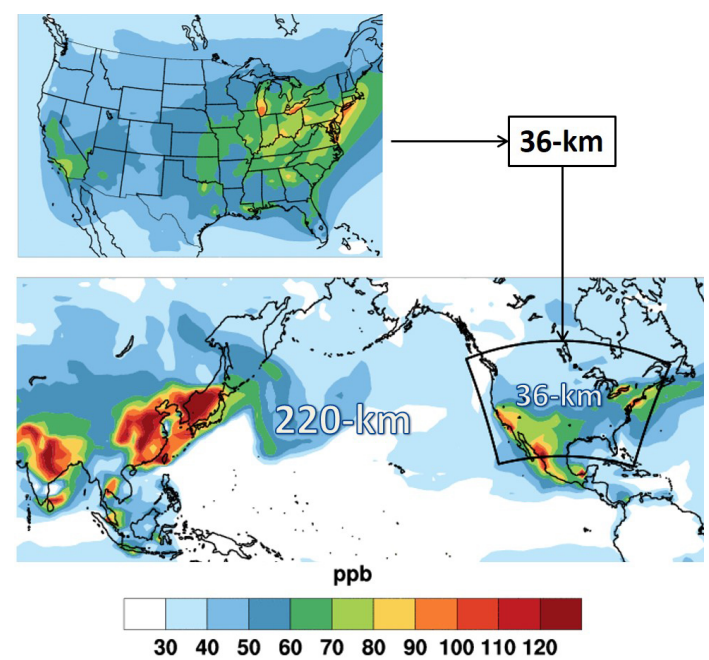

Figure 1. Projected future DM8O concentrations with future anthropogenic and biogenic emissions for the 220 and $36 \mathrm{~km}$ CMAQ modeling domains.

the fact that emission inventories can substantially change from one decade to the next suggests that using 5 to 10 year periods for air quality assessment is more appropriate. Thus, five representative summers (June-July-August; with May as a spin-up period) for the present (1995 to 2004) and the future (2045 to 2054) decades were selected. Ranked in terms of their CONUS-mean maximum temperature of the year, the summers of the warmest and coldest years, as well as the second, fifth and seventh warmest years in each decade were selected for CMAQ simulations. Comparison of the meteorological conditions of these five selected summers to those of the full decades is presented in Sect. 3.1. These five representative summers for the present and future periods were processed with the meteorology-chemistry interface processor v3.4.1 (MCIP; Otte and Pleim, 2010) for the S-HEM and $36 \mathrm{~km}$ CONUS domains. Meteorological fields generated from MCIP for both domains were used to estimate biogenic emissions using the Model of Emissions of Gases and Aerosols from Nature v2.04 (MEGANv2.04; Guenther et al., 2006) and to calculate the temporal profiles within the Sparse Matrix Operator Kernel Emissions (SMOKE) v2.7 (http://www.smoke-model.org). With the elements described above, a framework to perform air quality simulations using the CMAQ4.7.1 (Foley et al., 2010) was created. The overall schematic for the modeling system is shown in Fig. 2.

\subsection{Climate and meteorology}

The regional weather model WRF includes advanced representations of land-surface dynamics and cloud microphysics to simulate complex interactions between atmospheric processes and the land surface characteristics. Detailed descriptions of WRF can be found at http://wrf-model.org and a discussion of its range of regional climate modeling applica- 


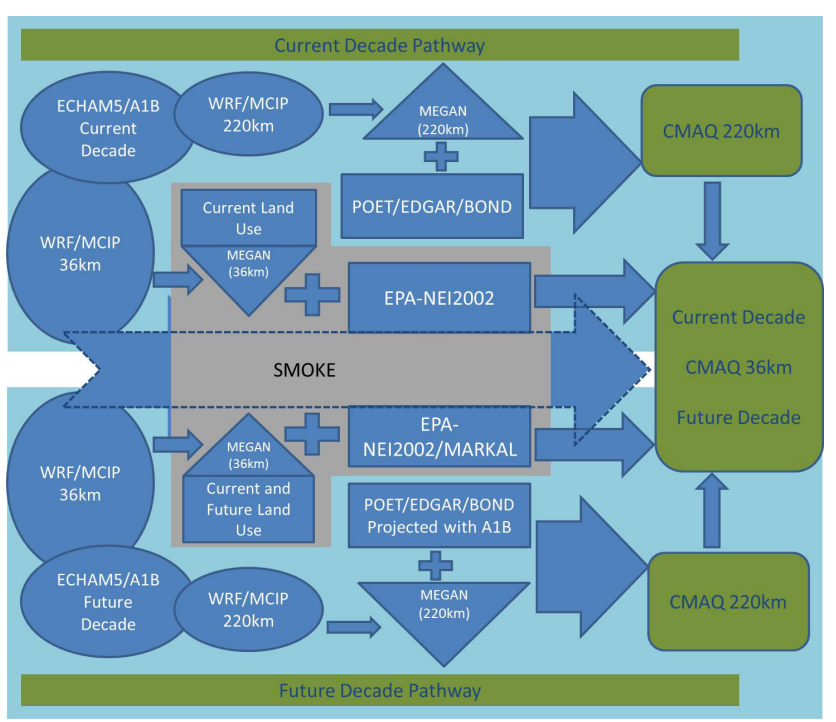

Figure 2. Schematic of the modeling framework.

tions is detailed by Leung et al. (2006). In this experiment, WRF was used to downscale the ECHAM5 output for both the S-HEM and 108/36 km CONUS domains. The model was applied with 31 vertical levels and a vertical resolution of $\sim 40-100 \mathrm{~m}$ throughout the boundary layer with the model top fixed at $50 \mathrm{mb}$. Details of the model setup and a discussion of the results are reported by Salathé et al. (2010), Zhang et al. $(2009,2012)$ and Duliére $(2011,2013)$.

\subsection{Current and future biogenic emissions and land use changes}

The MEGANv2.04 biogenic emission model (Guenther et al., 2006; Sakulyanontvittaya et al., 2008) was used to estimate current and future BVOC and soil $\mathrm{NO}_{x}$ emissions based on the WRF meteorology with current and future estimates of land use and land cover. For the current decade, the default MEGANv2.04 land cover and emission factor data (Guenther et al., 2006) were used. For the future decade, cropland distributions were estimated by combining three data sets: the IMAGE 2100 global cropland extent data set, (Zuidema et al., 1994), the SAGE maximum cultivable land data set (Ramankutty et al., 2002) and the MODIS-derived current cropland data (as used in MEGANv2.04 and described in Guenther et al., 2006). The IMAGE 2100 data set was created from the output of a land cover model, which forms part of a sub-system of the IMAGE 2.0 model of global climate change (Alcamo, 1994). The SAGE cultivable data set was created using a 1992 global cropland data set (Ramankutty and Foley, 1998) modified by characterizing limitations to crop growth based on both climatic and soil properties. The future global cropland extent distribution was generated by analyzing predicted changes in agriculture on a continent-by-continent basis (using the IMAGE data). These changes were then applied to the MODIS based cropland map (used for present-day MEGAN simulations) using the SAGE maximum cultivable data set as an upper limit to cropland extent. The resulting land cover data have considerably lower cropland fraction than the original IMAGE data, which likely overestimates future cropland area by not considering whether a location is cultivable.

In addition to generating a future crop cover data set to simulate potential biogenic VOC emissions using MEGAN, future data sets representing several other MEGAN driving variables were developed. These included geo-gridded potential future plant functional type (PFT)-specific emission factor (EF) maps for isoprene and terpene compounds, as well as future-extent maps of four non-crop PFTs: broadleaf trees, needle-leaf trees, shrubs and grasses. For regions outside of the US, the non-crop PFT distributions were generated by reducing the current extent of each non-crop PFT map by an amount that would appropriately offset the predicted cropland expansion for a given continent. For the US, future non-crop PFT maps were generated using the Mapped Atmosphere-Plant-Soil System (MAPSS) model output (http://www.fs.fed.us/pnw/mdr/mapss/; Neilson, 1995), based on three GCM future scenarios. Presentday MAPSS physiognomic vegetation classes were associated with current PFT fractional coverage estimates by dividing the US into sub-regions and by averaging existing (MODIS-derived) geospatially explicit PFT data within each sub-region as a function of MAPSS class. Sub-regions were created based on Ecological Regions of North America (http: //www.epa.gov/wed/pages/ecoregions.htm). After every current MAPSS class had been assigned PFT-specific fractional coverage estimates, future PFT cover was determined by reclassifying future distribution maps for the three MAPSS data sets using the fractional PFT cover estimates for each MAPSS class (within each ecological region), and averaging the three resultant future data sets into a single estimate of future cover for each PFT.

For the eastern US, future isoprene and monoterpene PFTspecific EF maps were constructed using changes in tree species composition predicted by the US Department of Agriculture "Climate Change Tree Atlas" (CCTA; http://nrs. fs.fed.us/atlas/tree/). The CCTA data are based on ecosystem changes driven by the average of three GCMs that represented the most conservative emissions scenarios available.

Using existing speciated EF data (Guenther, 2013), we applied anticipated changes in the average species composition of each PFT to generate species-weighted PFT-specific EF maps on a state-by-state basis (the CCTA data are organized by state). As data were lacking on predicted species-level changes for areas outside the eastern US, we did not attempt to alter EF maps outside the eastern US. 


\subsection{Anthropogenic emissions}

For S-HEM domain CMAQ simulations, global emissions of ozone precursors from anthropogenic, natural and biomass burning sources were estimated for the period 1990-2000 (applied to 1995-2004) using the POET emission inventory (Granier et al., 2005). Non-US anthropogenic emissions (containing 15 sectors) were projected based on national activity data and emission factors. Gridded maps (e.g., population maps) were applied to spatially distribute the emissions within a country. The global emission inventory for black and organic carbon (BC and $\mathrm{OC}$, respectively) was obtained from Bond et al. (2004), which applies emission factors based on fuel type and economic sectors alone. The Bond et al. (2004) inventory includes emissions from fossil fuels, biofuels, open burning of biomass, and urban waste. Emissions are varied by combustion practices, which consider combinations of fuel, combustion type and emission controls, as well as their prevalence on a regional basis.

Global emissions for the year 2000 from the POET, MEGAN and Bond et al. (2004) inventories were combined, and the 16 gas-phase POET and MEGAN species, along with the OC and BC species were adapted to the Statewide Air Pollution Research Center (SAPRC)-99 (Carter, 1990, 2009) chemical mechanism. Diurnal patterns were developed and applied to the gridded emission inventories and processed using SMOKE. For the future decade hemispheric domain simulations, current decade emissions were projected to the year 2050 based on the IPCC A1B emission scenario. The percent change in emissions was summarized according to the regions and countries in the S-HEM domain that surround the CONUS domain (Fig. 3).

US anthropogenic emissions for the $36 \mathrm{~km}$ CONUS current decade CMAQ simulations were developed using the 2002 National Emission Inventory. The Emission Scenario Projection (ESP) methodology, version 1.0 (Loughlin et al., 2011), was applied to project future decade US anthropogenic emissions. A primary component of ESP v1.0 is the MARKet Allocation (MARKAL) energy system model (Loulou et al., 2004). MARKAL is an energy system optimization model that characterizes scenarios of the evolution of an energy system over time. In this context, the energy system extends from obtaining primary energy sources, through their transformation to useful forms, to the variety of technologies (e.g., classes of light-duty personal vehicles, heat pumps, or gas furnaces) that meet "end-use" energy demands (e.g., projected vehicle miles traveled, space heating). Within ESP 1.0, MARKAL is used to develop multiplicative factors that grow energy-related emissions from a base year to a future year. Surrogates, such as projected population growth or industrial growth, are used to develop nonenergy-related growth factors. The resulting factors were applied within SMOKE to develop a future decade inventory from the 2002 National Emissions Inventory (NEI).

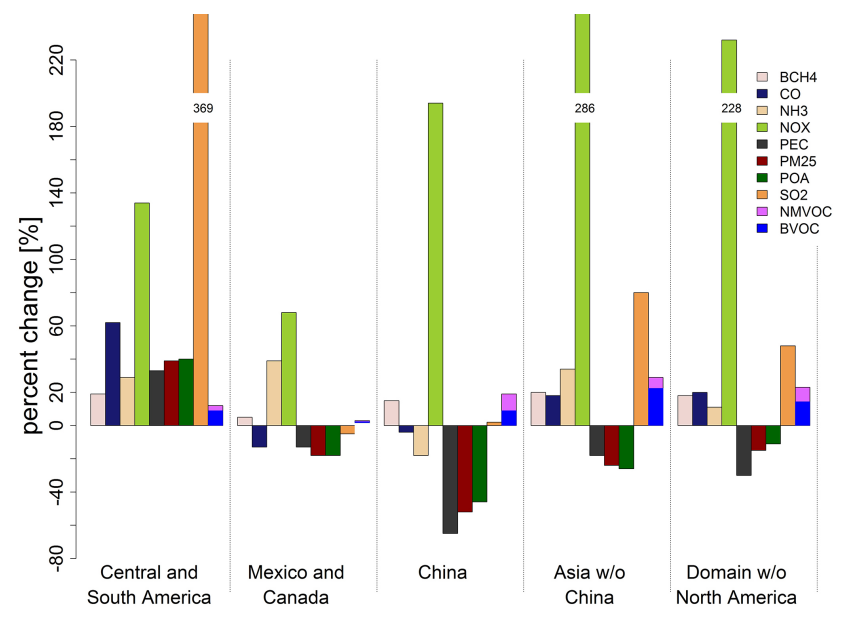

Figure 3. Summary of regional changes in global anthropogenic and biogenic emissions.

For the work presented here, the EPAUS9r06v1.3 database (Shay et al., 2006) was used with MARKAL to develop growth factors for $\mathrm{CO}_{2}, \mathrm{NO}_{x}, \mathrm{SO}_{2}$ and $\mathrm{PM}$ with aerodynamic diameter smaller than $10 \mu \mathrm{m}\left(\mathrm{PM}_{10}\right)$. The $\mathrm{PM}_{10}$ growth factors were also applied to $\mathrm{PM}_{2.5}$, and the $\mathrm{CO}_{2}$ growth factors were used as a surrogate for energy system $\mathrm{CO}, \mathrm{NH}_{3}, \mathrm{VOC}, \mathrm{HCl}$ and chlorine. For mobile sources, $\mathrm{NO}_{x}$ growth factors were used for $\mathrm{CO}, \mathrm{VOC}$ and $\mathrm{NH}_{3}$. Noncombustion industrial emission growth factors were developed from projections of economic growth. Growth factors for non-combustion emissions from the residential and commercial sectors are linked to population growth. The resulting energy and non-energy factors were then used within SMOKE to multiply emissions from the 2002 NEI to 2050.

EPAUS9r06v1.3 originally was calibrated to mimic the fuel use projections of the US Energy Information Administration's 2006 Annual Energy Outlook (AEO06; US DOE, 2008). Energy demands were adjusted to account for population growth consistent with the A1B storyline. The results reflect business as usual assumptions about future environmental and energy regulations as of 2006. Thus, while electric sector emissions are capped to capture the effects of the Clean Air Interstate Rule (CAIR; US EPA, 2005), the impacts of increases in natural gas availability, the 2007 economic downturn, and the relatively new 54.5 Corporate Average Vehicle Efficiency (CAFÉ) standard (US CFR, 2011) are not reflected. More recent versions of the MARKAL database reflect these factors with expanded pollutant growth coverage and refined emission factors (US EPA, 2013). The ESP v1.0, including the MARKAL database EPAUS9rv1.3, was selected here to maintain compatibility with previous and ongoing activities.

The differences between the base year and future-year US inventories were summarized at the pollutant and regional level (Fig. 4). Using the ESP v1.0 methodology, emissions of 


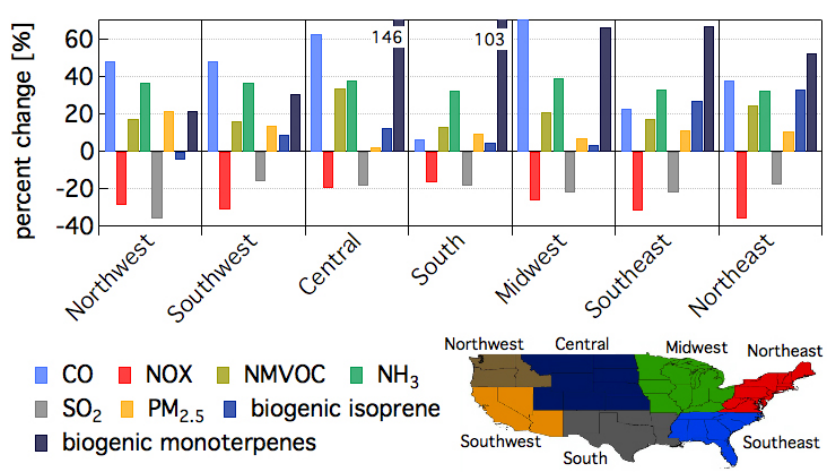

Figure 4. Summary of regional changes in US anthropogenic and biogenic emissions from future decade land use.

$\mathrm{NO}_{x}$ and $\mathrm{SO}_{2}$ are projected to decrease between $16 \%$ in the South and Southwest to $35 \%$ in the Northeast and Northwest. On the other hand, emissions of pollutants that were not captured endogenously by MARKAL, such as carbon monoxide (CO), non-methane volatile organic compounds (NMVOCs) and ammonia $\left(\mathrm{NH}_{3}\right)$ are projected to increase in nearly all regions across the CONUS domain. The use of surrogates for growth factors as described above means the projected changes in $\mathrm{CO}$ and VOC emissions are likely too high. The largest increase (70\%) in emissions of $\mathrm{CO}$ is projected in the Midwest; this is co-located with an increase of about $20 \%$ of NMVOC. The smallest increase of $\mathrm{CO}$ is projected for the South; however, the same region was projected to increase NMVOC by about $12 \%$. The largest increase in $\mathrm{PM}_{2.5}$ emissions is projected in the Northwest $(<20 \%)$ and the smallest increase $(3 \%)$ of $\mathrm{PM}_{2.5}$ is projected in the Central region, which also has a projected $34 \%$ increase in NMVOC.

\subsection{Air quality simulations}

The CMAQ model version 4.7.1 was employed to simulate the potential impact of climate change on surface ozone and $\mathrm{PM}_{2.5}$ over the CONUS at $36 \mathrm{~km}$ horizontal grid spacing and covering 18 vertical layers from the surface up to $100 \mathrm{mb}$. The model configuration included the use of the SAPRC-99 chemical mechanism and version 5 of the aerosol module, with secondary organic aerosol (SOA) parameters of Carlton et al. (2010). Methane concentration is fixed at 1.85 parts per million (ppm) for all CMAQ simulations. Stratospheric intrusion (STE) was not included in the CMAQ simulations; high STE events are mostly relevant during the spring season; thus, lack of STE in our summer simulations is not expected to have a significant effect in our results.

Using the framework components described above, a matrix of CMAQ simulations that included changes in predicted meteorological conditions and potential emission scenarios was constructed (Table 1). For each set of simulations shown in Table 1, five representative summers were modeled. Simulation 0 represents the base case simulation, where all model
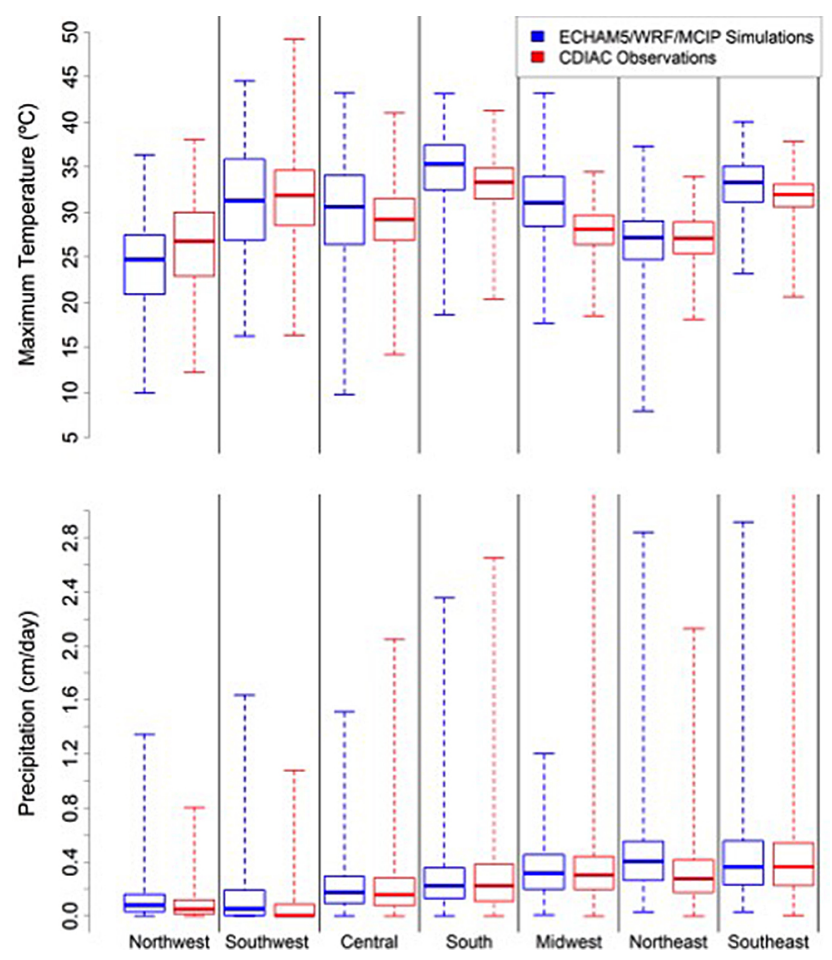

Figure 5. Comparison of modeled and observed seasonal-mean meteorological variables by region: maximum daily temperatures (top); and precipitation rates (bottom). Each box-and-whisker indicates median, 25 and $75 \%$ quartiles, maximums and minimums of the values across all sites within each region.

inputs are set to current decade conditions. Simulation 1 is used to investigate the impact of climate change alone: all model inputs are set to current decade conditions except for meteorology (biogenic emissions are not allowed to change with the future climate for this case). Simulation 2 is the same as Simulation 1, except that biogenic emissions are allowed to change with the future climate, and in Simulation 3, future land use is also incorporated into the biogenic emission estimates. Simulation 4 is used to investigate the impact of future decade US anthropogenic emissions, where all inputs are set to current decade levels except for US anthropogenic emissions. The impact of future global emissions is investigated in Simulation 5. Finally, Simulation 6 represents the combined impacts of Simulations 1-5.

\subsection{Evaluation of model performance}

To aid in summarizing model results, the $36 \mathrm{~km}$ domain was divided geographically into seven regions (Fig. 4, lower right). Since the WRF simulations used to drive CMAQ are based on a climate realization rather than reanalysis data, a direct comparison between the modeled output and observations cannot be made. Instead, the frequency distributions of simulated and observed values are compared. For the simulated meteorological fields, daily maximum temperature and 
Table 1. List of simulations to assess the effect of global climate changes upon air quality in the United States.

\begin{tabular}{ccccccc}
\hline & Climate & \multicolumn{2}{c}{ Biogenic emissions } & & \multicolumn{2}{c}{ Anthropogenic emissions } \\
\cline { 3 - 3 } \cline { 5 - 6 } \cline { 5 - 6 } & & climate & land use & & USA & global \\
\hline 0 & Current & Current & Current & & Current & Current \\
1 & Future & Current & Current & & Current & Current \\
2 & Future & Future & Current & & Current & Current \\
3 & Future & Future & Future & & Current & Current \\
4 & Current & Current & Current & & Future & Current \\
5 & Current & Current & Current & & Current & Future \\
6 & Future & Future & Future & & Future & Future \\
\hline
\end{tabular}

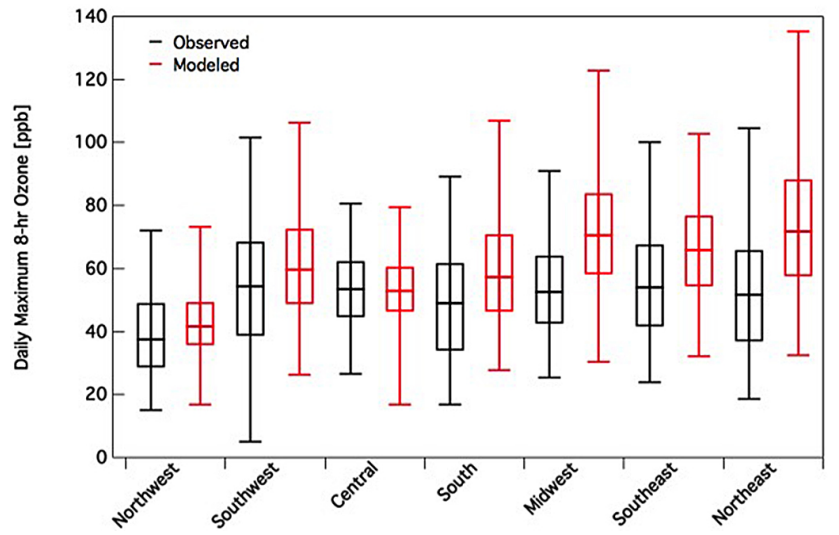

Figure 6. Shown are the 2nd, 25th, 50th, 75th, 98th percentiles of observed vs. modeled values of DM8O for each region.

daily precipitation are compared against a decade of summer observations (1995-2004) from the United States Historical Climatological Network (US-HCN; http://cdiac.ornl.gov/ftp/ ushcn_daily/; Karl et al., 1990) in Fig. 5. The model distributions of temperature and precipitation agree reasonably well with the observations, and provide a good representation of the regional variability of precipitation and temperature. Except for the Northwest and Southwest regions, the observed mean and maximum temperatures are over predicted, with the largest overprediction in the Midwest. For all analyzed regions the model successfully simulates the seasonal trend of summer temperatures, showing the observed increase in mean temperature from June to July and subsequent decrease in mean temperature from July to August (not shown).

The modeled daily maximum $8 \mathrm{~h}$ ozone concentrations (DM8O) from the five representative summers (Fig. 6) from the current decade CMAQ simulations (Simulation 0) were compared to the range of observations from the AIRNow network (http://airnow.gov/). As seen in Fig. 6, DM8O is overestimated in regions where temperature maxima are also over predicted, most noticeably in the Midwest, the South and the Southeast but also in the Northeast. Except for the less populated Central region, DM8O shows a bias that ranges between $+10 \mathrm{ppb}(+15 \%)$ and $+25 \mathrm{ppb}(+37 \%)$ across the

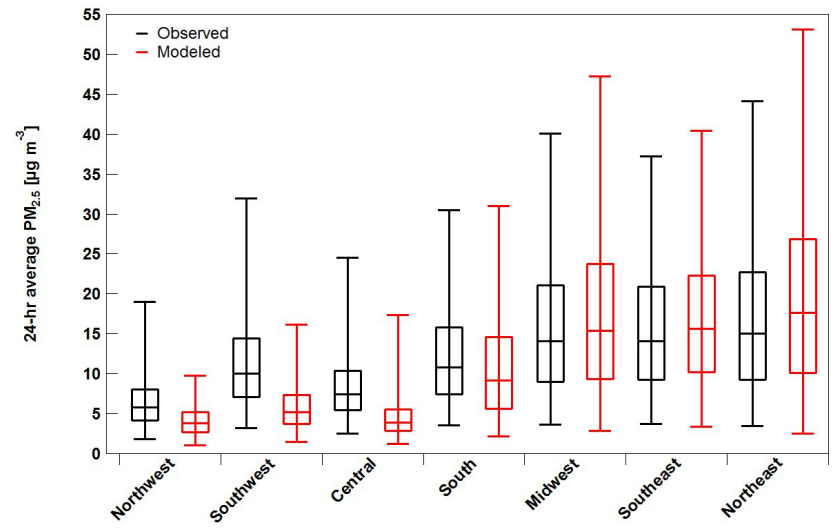

Figure 7. Shown are the 2nd, 25th, 50th, 75th, 98th percentiles of observed vs. modeled values of $24 \mathrm{~h}$ average $\mathrm{PM}_{2.5}$ for each region.

domain. This is consistent with previous climate downscaled results by Tagaris et al. (2007), who found a bias of $+15 \%$, and with Avise et al. (2009), who found regional biases as high as $+39 \%$. Despite the bias, results from the modeling framework presented here have been shown to accurately represent the correlation between ozone and temperature at rural Clean Air Status and Trends Network (CASTNET) sites throughout the US (Avise et al., 2012), suggesting that the bias in temperature is the main cause of the bias in DM8O. This implies that the CTM is responding to the meteorological driver of ozone production and thus can predict the impact of climate change on DM8O.

Simulations for the current decade show a domain-average DM8O of $66 \pm 20 \mathrm{ppb}$ (standard deviation between simulated DM8O for the five summers), while the observed average at the AIRNow sites was $56 \pm 18 \mathrm{ppb}$. The simulations successfully captured the enhanced DM8O concentrations over the major urban areas and regions with high biogenic sources (Fig. 12a). Interannual variability of the simulated summer DM8O concentrations is on the order of $10 \%$ (not shown) in highly populated areas and as little as $1 \%$ in less populated areas, with the greatest variability found in the Northeast region. 


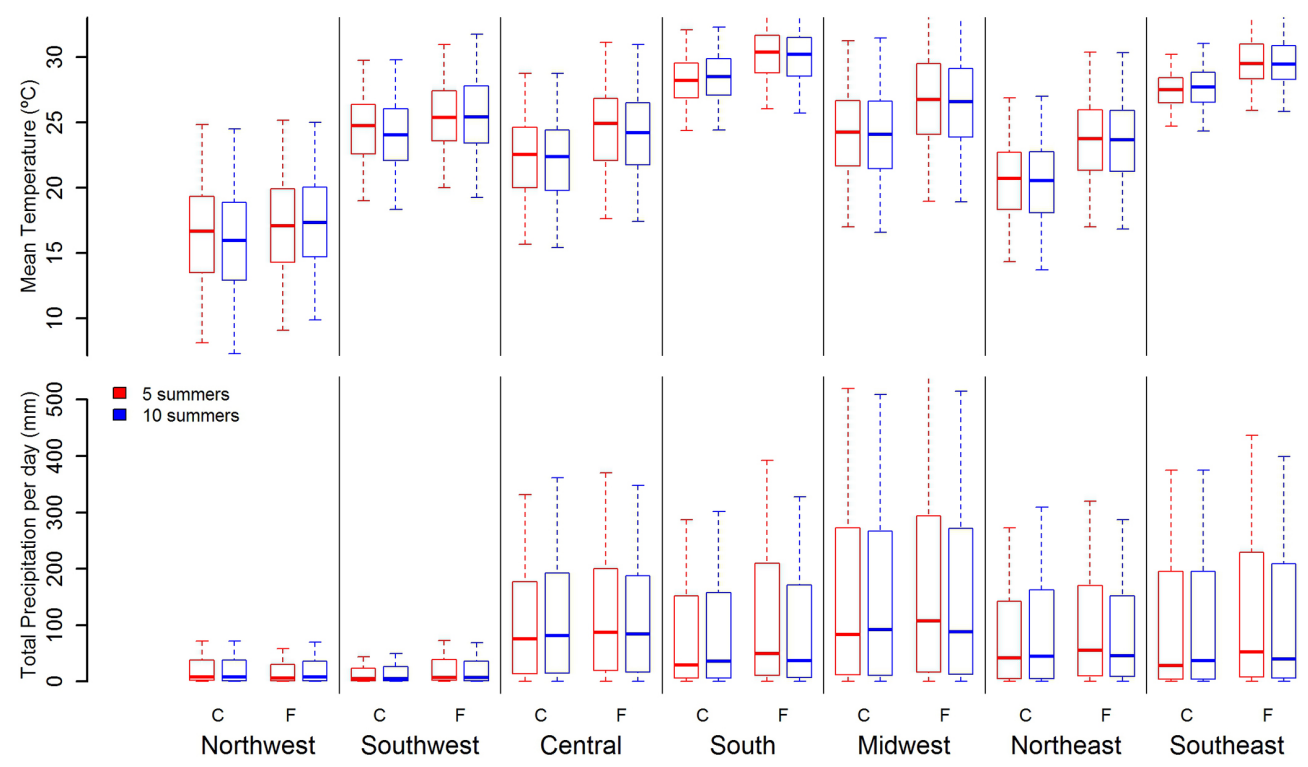

Figure 8. (Top panel) mean regional temperature for the five chosen summers (red) and ten summers (blue) of the current (C) and future (F) decades. (Bottom panel) total regional precipitation per day for the five chosen summers (red) and ten summers (blue) of the current (C) and future $(\mathrm{F})$ decades. Each box-and-whisker indicates median, 5, 25, 75 and $95 \%$ quartiles within each region.

Simulated concentrations of current decade $\mathrm{PM}_{2.5}\left(\mathrm{PM}_{2.5}\right.$ with no water content, unless otherwise specified) show a five summer average of $12.05 \pm 10.8 \mu \mathrm{g} \mathrm{m}^{-3}$, compared to $14.3 \pm 9.2 \mu \mathrm{g} \mathrm{m}^{-3}$ observed at the Speciation Trends Network (STN; US EPA, 2000). In general, the model slightly overestimates $\mathrm{PM}_{2.5}$ in the Midwest, the Southeast and the Northeast and significantly underestimates $\mathrm{PM}_{2.5}$ in the western half of the US (Fig. 7). Several factors contribute to the underestimation of $\mathrm{PM}_{2.5}$ in the western US, including a lack of windblown dust and fire smoke emissions, and an underestimation of SOA formation (Carlton et al., 2010; Foley et al., 2010; Appel et al., 2012; Luo et al., 2011). Another important factor that influenced the underestimation of $\mathrm{PM}_{2.5}$ is the overprediction of precipitation as shown in Fig. 5

\section{Results and discussion}

\subsection{Projected changes in meteorology}

For these types of climate change simulations, it is important to consider whether the five selected summers represent the climatological conditions for the 1995-2004 and 20452054 periods. To address this, we compared the regional mean temperature and total precipitation (Fig. 8) as well as maximum daily insolation and mean relative humidity (not shown) for all ten summers versus the five selected summers. Based on the two sample $t$ test, except for the Northwest region, we found no statistical difference in the overall regional average conditions between the five and ten summer samples $(p>0.01)$. For the purposes of this air quality assessment, this comparison of the meteorological conditions for the five selected summers to the full ten summer set of data suggest that the five summers provide a reasonable representation of decadal summer meteorological conditions. While no statistical difference was found between the five and ten summer samples, some distinct features should be highlighted: (1) for the current decade, except for the Southeast, the chosen set of five summers on average is slightly warmer than the average of the ten summers; (2) the five summers chosen for current and future decades led to a projection of cooling in the Northwest. The effects of the higher average temperature as result of the five summer sample, and the projected decrease in future temperature in the Northwest are discussed below.

Similar to the 30 year meteorological variability assessment carried out by Andersson and Engardt (2010), the differences between current and future summer meteorological conditions, based on the five representative periods, were found to be significant at the $99 \%$ confidence level for all regions except for the Northwest. This further supports the use of five representative summers as the basis for the air quality assessment of current and future conditions.

Projected changes in selected meteorological parameters are shown in Fig. 9. Except for some minor cooling along the Pacific coast, mean summer temperature across the continental US is projected to increase between 0.5 and $4{ }^{\circ} \mathrm{C}$ (Fig. 9a). This increase falls within the lower bound of the warming predicted by the ensemble of 20 GCMs under the A1B emission scenario described by Christensen et al. (2007), but differs in the regional variability due to the higher resolution of our simulations. When compared to similar studies of equal resolution using a GCM (e.g., Goddard Institute for Space 

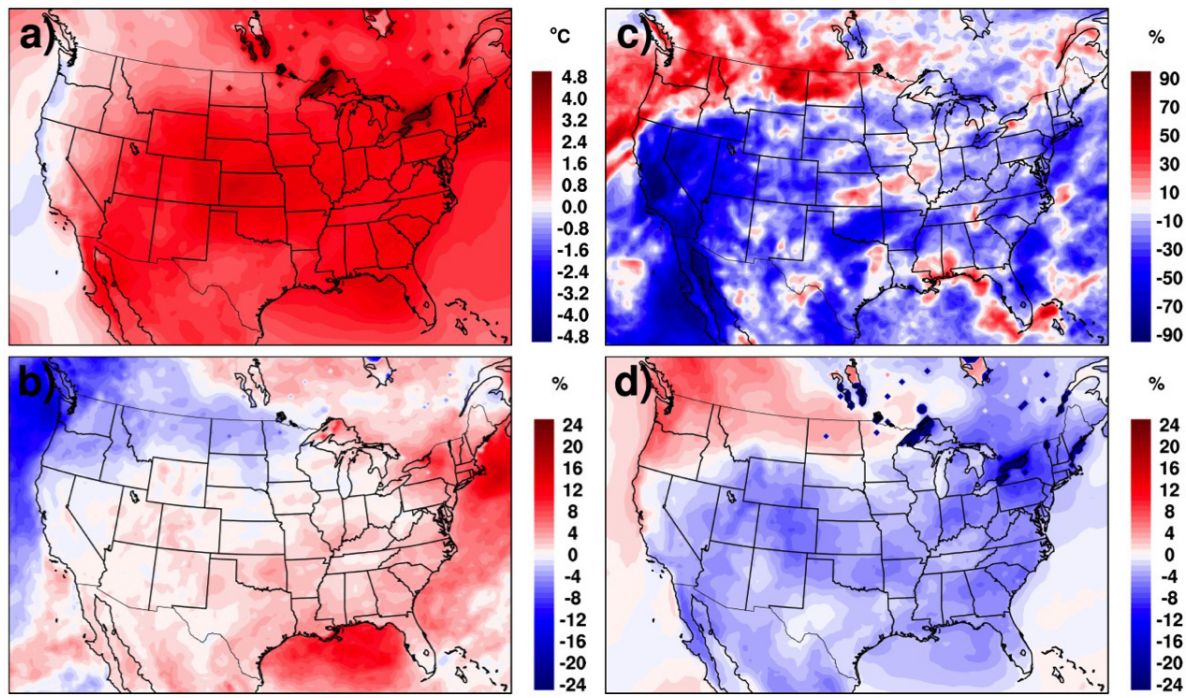

Figure 9. Projected changes in summertime meteorological fields (future decade-current decade): (a) changes in $2 \mathrm{~m}$ temperature $\left({ }^{\circ} \mathrm{C}\right.$ ); (b) percent change in solar radiation reaching the ground; (c) percent change in precipitation; (d) change in relative humidity.

Studies (GISS) GCM II) driven by the A1B IPCC emission scenario and downscaled with MM5 to $36 \mathrm{~km}$ resolution, our simulated temperatures show higher temperature differences between future and current decades (Leung and Gustafson, 2005; Tagaris et al., 2007). Tagaris et al. (2007) and Leung and Gustafson (2005) predicted an average increase of between 1 and $3{ }^{\circ} \mathrm{C}$ for most of CONUS, and temperature reductions in the border states of the Central and South regions. Nevertheless, despite the differences in physical parameterizations contained in the GCMs and the driving IPCC emission scenarios that were used, similar temperature differences $\left(2\right.$ to $\left.4{ }^{\circ} \mathrm{C}\right)$ between our study and previous investigations were simulated for the Northeast and Southeast regions (Leung and Gustafson, 2005; Tagaris et al., 2007; Avise et al., 2009).

Projected increases in solar radiation reaching the ground vary by region. A decrease in solar radiation in the Northwest that extends to the northern boundaries of the Central regions is simulated. Small changes in the Southwest, South and Midwest are also predicted, with the largest increase experienced in the Northeast and Southeast regions (Fig. 9b). Similar results for the Northeast regions are reported by previous investigations (Leung and Gustafson, 2005; Tagaris et al., 2007; Avise et al., 2009); however, these same investigations had higher reductions in solar radiation at the border states between the Central and South regions.

Projected changes in precipitation across the US also vary depending on the region. With the exception of the Northwest and the northern boundary of the Central region, summertime precipitation is projected to decrease between -10 and $-80 \%$. The largest decrease is projected in the Southwest region. Our results show greater precipitation reductions than those presented in Christensen et al. (2007), who projected between a 5 to $15 \%$ decreases in the South and Southwest regions. Also, previous investigations agreed with our projected mean precipitation reductions across the domain (Fig. 9c). In the Northwest, the modeled increase in precipitation is consistent with Leung and Gustafson (2005), who projected an increase in precipitation throughout the Northwest region. In contrast, the Southeast and Northeast regions show disparities in the magnitude and the sign of the change in precipitation. While our simulations show a reduction in precipitation between 10 to $20 \%$, the ensemble of 20 GCMs in Christensen et al. (2007) resulted in an increase between 5 to $10 \%$ across these regions. The disparities may be a result of the differences in resolution and parameterization schemes between our study and those used for the $20 \mathrm{GCMs}$.

Changes in relative humidity are shown in Fig. 9d. Relative humidity is shown to decrease in most of the domain except for the regions where decreases in solar radiation were projected. The greater decrease in relative humidity occurs in the Southwest and Central regions of the domain, and the largest increase is observed in the Northwest region.

\subsection{Changes in biogenic emissions}

Average summertime isoprene emissions over five summers of simulation for each decade are shown in Fig. 10a. Isoprene emissions occur at relatively high rates $(>50$ metric tons day $^{-1}$ ) in the eastern US and at much lower rates in the western US $\left(<10\right.$ metric tons day $\left.{ }^{-1}\right)$. Under future climate conditions and current land use, isoprene and monoterpene emissions are projected to increase in all regions except for the Northwest (Figs. 4 and 10b); this follows the spatial pattern of projected temperature changes (Fig. 9a). The most noticeable increases occur in the Northeast and Southeast 

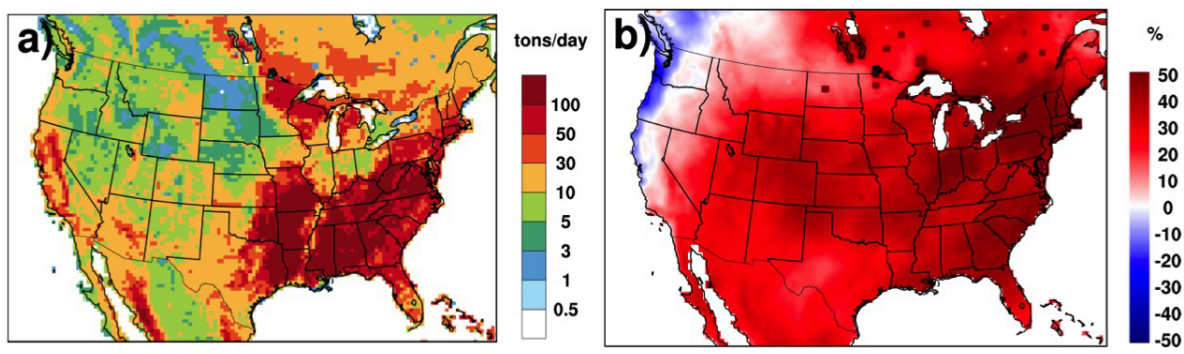

Figure 10. (a) Current decade summertime isoprene emissions, and (b) percent change induced by climate on future summertime isoprene emissions with current decade land use.
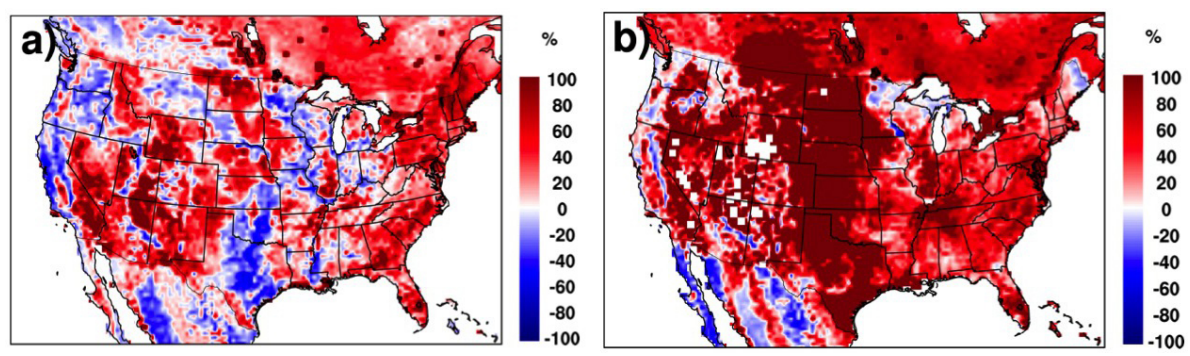

Figure 11. Percent change between future and current decade summertime emissions for future climate and land use for (a) isoprene and (b) monoterpene.

regions. The model projects a larger percentage increase in monoterpenes than isoprene across the domain; however, total isoprene emission is an order of magnitude higher and thus dominates the changes in total BVOC. The increase in total BVOC ranges between 17 and $45 \%$. The only region that is projected to have reduced total BVOC emissions is the Northwest, where the model simulates a $7 \%$ reduction in isoprene emissions (Fig. 4) that in absolute amounts is greater than the $20 \%$ increase in simulated monoterpene emissions. The reduction in isoprene emissions in the Northwest is a result of the decrease in temperatures in the coastal area where the higher isoprene emissions are encountered (Fig. 9a). Previous investigations (Liao et al., 2006; Nolte et al., 2008) show the greatest increase in BVOC emissions in the Southeast region (10-50 \%). Similarly, Nolte et al. (2008) predicted the greatest increase in BVOC in the Southeast, but did not show any significant changes in the Northwest region.

When future climate is combined with future land use to project biogenic emissions, the spatial extent of isoprene emission increase is reduced, reflecting the expansion of low isoprene-emitting croplands into regions of high isopreneemitting deciduous forests. In this case, the domain-average increase was approximately $12 \%$ of current decade emissions, compared with a $25 \%$ increase when changes in land use are not included (Fig. 11a). Thus, future expansion of cropland and subsequent reduction of broadleaf forested lands are projected to lessen the overall increase in US isoprene emissions that result from a warmer climate. When the future decade meteorology is combined with future land use, an increase of over $100 \%$ of current decade monoterpene emissions is predicted (Fig. 11b). The growth is most noticeable in the Central, South and Midwest regions. Also, an overall increase between 25 and $50 \%$ for the western and eastern regions is simulated. This limited increase is primarily driven by the projected changes in land use predicted for those regions.

Since the version of MEGAN used in this work does not include the suppression of isoprene emissions due to elevated concentrations of $\mathrm{CO}_{2}$ (Rosenstiel et al., 2003; Heald et al., 2009), the future estimates in this study are likely to be an upper bound on isoprene emissions, and it is likely that future isoprene emissions will be lower than predicted by this work. Monoterpene emissions from US landscapes are not expected to be suppressed by increasing $\mathrm{CO}_{2}$ and so are not impacted by omitting this process.

\subsection{Effects of global changes upon ozone concentrations}

Results for how the various global changes affect summertime DM8O are summarized in Table 2 and Fig. 12. Simulations for the future decade (Simulation 6) show a domain average of $48 \pm 11 \mathrm{ppb}$ with higher DM8O in the Northwest, Central and South regions than the current decade simulation (Simulation 0). In general, increases in DM8O are due to growing global anthropogenic emissions and climate change, while decreasing US emissions reduce DM8O. Changes in biogenic emissions as a result of a changing climate and land use have less of an influence on DM8O than an increase of 
Table 2. Percent change in DM8O between each future scenario and the current decade base case.

\begin{tabular}{lcccccc}
\hline Region & $\begin{array}{c}\text { Climate } \\
(1)\end{array}$ & $\begin{array}{c}\text { Climate } \\
\text { \& BVOC } \\
(2)\end{array}$ & $\begin{array}{c}\text { Climate, } \\
\text { BVOC, } \\
\text { land } \\
\text { use (3) }\end{array}$ & $\begin{array}{c}\text { US } \\
\text { anthropogenic } \\
\text { emissions } \\
(4)\end{array}$ & $\begin{array}{c}\text { Boundary } \\
\text { conditions } \\
(5)\end{array}$ & $\begin{array}{c}\text { Combined } \\
(6)\end{array}$ \\
\hline \multicolumn{7}{c}{ DM8O } \\
Northwest & 0.4 & -1.0 & -0.8 & -0.6 & 8.1 & 4.5 \\
Southwest & 2.0 & 0.4 & 0.0 & -3.5 & 9.1 & 4.2 \\
Central & 5.6 & 4.5 & 4.9 & -0.1 & 8.9 & 12.3 \\
South & 6.2 & 4.3 & 6.1 & -0.9 & 9.6 & 13.0 \\
Midwest & 7.6 & 7.2 & 8.5 & 0.0 & 2.6 & 10.0 \\
Northeast & 8.2 & 6.6 & 7.6 & -2.3 & 1.4 & 5.3 \\
Southeast & 8.6 & 6.1 & 7.7 & -3.0 & 3.3 & 6.1 \\
\hline
\end{tabular}

global anthropogenic emissions. Factors that influence future DMO3 are discussed in the following sections.

\subsubsection{Contributions from changes in global and US anthropogenic emissions}

The effects of increased long-range transport of global emissions are shown in Fig. 12f. The changes in chemical boundary conditions (the difference between Simulations 0 and 5) increase DM8O between 2 to $6 \mathrm{ppb}$ across the CONUS domain. The general west-to-east and south-to-north gradients of the change in DM8O reflects intercontinental and regional transport of ozone and its precursors from the west and from Mexico at the south. The greatest impact occurs in the South $(6 \mathrm{ppb})$ and Southwest $(5 \mathrm{ppb})$ regions. These results show a smaller influence in DM8O from the intercontinental transport than the simulations presented in Avise et al. (2009), who report increases between 3 and 6 ppb of DM8O across the domain, with the greatest increase in the Southwest and South regions. The higher effect from intercontinental transport presented in Avise et al. (2009) is due to larger increases $\mathrm{NO}_{x}$ emissions from global anthropogenic sources under the SRES A2 emission scenario. The effects of future global emissions and intercontinental transport of ozone precursors in the continental US have also been investigated by Hogrefe et al. (2004), who predicted an increase of $5 \mathrm{ppb}$ in the Northeast region under the SRES A2 emission scenario.

Changes in regional US emissions of ozone precursors (difference between Simulations 0 and 4) reduce DM8O concentrations between 2 and $15 \mathrm{ppb}$ in most of eastern US, most of western US and Texas. Projected increases in ozone in urban areas near the coasts are mainly due to the limited representation of the heavy-duty, shipping and rail sectors on the ESPv1.0 (Loughlin et al., 2011) by which local steady or increase in emissions of $\mathrm{NO}_{x}$ and VOCs in ports are the main cause of increase in ozone in those urban areas. Regionally, larger reductions are observed in the Southeast $(-3 \%)$ and Southwest $(-3.5 \%)$ regions with a reduction of $5 \mathrm{ppb}$ and the Northeast $(-2.3 \%)$ and South $(-0.9 \%)$ re-

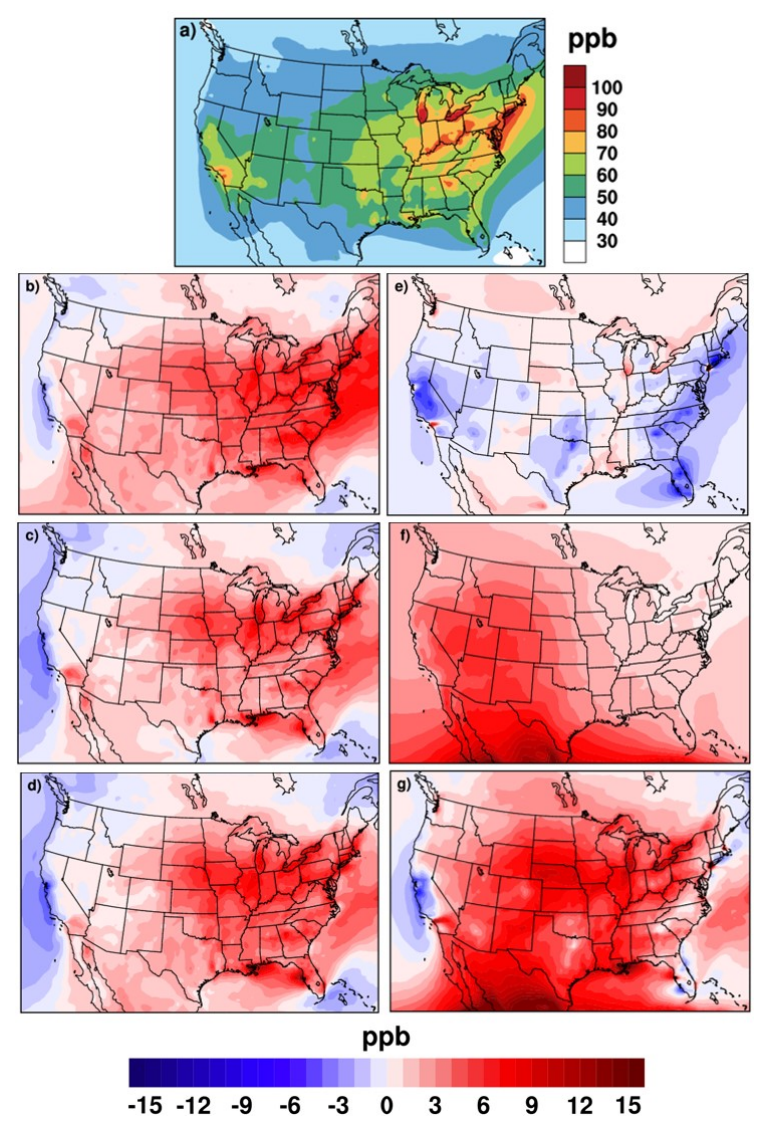

Figure 12. (a) Current decade base case daily maximum $8 \mathrm{~h}$ ozone average concentrations for five summers in the 2000s; spatial distribution; and regional effect on maximum $8 \mathrm{~h}$ ozone due to (b) changes in meteorology (Simulation 1-Simulation 0); (c) changes in meteorology and biogenic emissions (Simulation 2 Simulation 0); (d) changes in meteorology, biogenic emissions, and land use (Simulation 3-Simulation 0); (e) changes in US anthropogenic emissions (Simulation 4-Simulation 0); (f) changes in global anthropogenic emissions (Simulation 5-Simulation 0); and (g) all the changes above combined (Simulation 6-Simulation 0). 
gions with a reduction of $3 \mathrm{ppb}$ (Fig. 12e, Table 2). Similar results are shown in Nolte et al. (2008) and Tagaris et al. (2007) despite a difference in the magnitude of projected emissions reductions. Tagaris et al. (2007) simulated similar ozone reductions (about $9 \%$ ), with a higher nationwide reduction of $51 \%$ in $\mathrm{NO}_{x}$ emissions and a slight increase (about $2 \%$ ) in VOC emissions from projections based on the CAIR emission inventory. Nolte et al. (2008) showed a decrease in ozone across the domain $(-12$ to $-16 \mathrm{ppb})$ as a result of projected reductions of $45 \%$ for $\mathrm{NO}_{x}$ and $21 \%$ for VOC emissions from the NEI 2002, following the SRES A1B emission scenario. In contrast, our future simulations included a $38 \%$ reduction in $\mathrm{NO}_{x}$ emissions and a slight increase (about $2 \%$ ) in VOC emissions. Avise et al. (2009) predicted an average contribution of +3 ppb across the domain as a result of projecting the NEI 1999 (NEI-1999) with the Economic Growth Analysis System (EGAS) and the SRES A2 emission scenario, increasing emissions by $5 \%$ for $\mathrm{NO}_{x}$ and $50 \%$ for VOCs in the future. The smaller reduction in ozone concentrations between the future and the current decade in comparison to Nolte et al. (2008) is likely to be a consequence of the increase in $\mathrm{VOC}$ and $\mathrm{CO}$ emissions from the business-as-usual scenario of MARKAL, which, as explained in Sect. 2.4, uses diverse surrogates for growth factors for CO and VOC (Loughlin et al. 2011).

\subsubsection{Contributions from changes in meteorological fields}

Figure 12b shows the difference between simulations that include changes in meteorological conditions (without the effect of biogenic emissions or land use) and the current decade base case (Simulations 0 and 1). The local reductions in DM8O concentrations in the Northwest resulted from an increase in cloud cover and lower solar radiation reaching the ground, which cause a reduction in photochemistry (Fig. 9b). For other regions, increases in DM8O concentrations were projected $(+5 \mathrm{ppb})$ because of increases in temperature and solar insolation; this is particularly evident in the eastern half of the US.

\subsubsection{Contributions from changes in biogenic emissions and future land use}

When biogenic emissions are allowed to change with the future meteorology, an average increase of DM8O with respect to the current decade base case simulations is predicted (Simulations 0 and 2). Increases of as much as $7 \mathrm{ppb}$ in DM8O concentrations are mainly predicted in areas with substantial biogenic sources (Fig. 12c). Similar results are shown by Nolte et al. (2008) and Tagaris et al. (2007); both predicted an increase of DM8O above $5 \mathrm{ppb}$ in the east coast. Simulated reductions between 2 and 4 ppb of DM8O in the coastal areas of the western regions are probably due to cooler temperatures and reduced solar insolation (Fig. 9a, b).
Minor changes in DM8O concentrations are shown over the Southwest and Northwest regions. This is in agreement with Avise et al. (2009) and Nolte et al. (2008) who predicted reductions in DM8O concentrations from 1 to $4 \mathrm{ppb}$ in the western regions, while Tagaris et al. (2007) also predicted similar reductions in ozone in the Central and Midwest regions. The disparities between this investigation and Avise et al. (2009) are reasonable due to the different climate realizations used (A2 vs. A1B; storyline in scenario A2 considers higher emissions of $\mathrm{CO}_{2}$ by 2050 than the scenario A1B). However, the difference in geographical features of DM8O changes with Nolte et al. (2008) and Tagaris et al. (2007) suggests that the source of disparities reside in the simulated regional meteorological fields resulting from different global climate models, RCMs and the methods used to estimate emissions from biogenic sources. We used the ECHAM5 global climate model results while both Nolte et al. (2008) and Tagaris et al. (2007) used results from the GISS global climate model. For regional climate simulations, we used WRF; both Nolte et al. (2008) and Tagaris et al. (2007) used MM5. In contrast with Nolte et al. (2008) and Tagaris et al. (2007) who use the BEIS/BELD3 (Hanna et al., 2005; http://www3.epa.gov/ttn/chief/emch/biogenic/) tool to compute biogenic emissions, this investigation estimates the biogenic emissions with MEGAN v2.04, which generally predicts higher isoprene emissions than BEIS (Hogrefe et al., 2011; Sakulyanontvittaya et al., 2012). Hogrefe et al. (2011) showed that MEGAN leads to higher DM8O in the Northeast by upwards of $7 \mathrm{ppb}$ under the scenario of 2005 anthropogenic emissions; however, for a scenario by which anthropogenic $\mathrm{NO}_{x}$ emissions were reduced by $\sim 60 \%$, the difference in DM8O was generally 3 ppb due to greater sensitivity to $\mathrm{NO}_{x}$ emissions when MEGAN was used.

When the results from Simulation 2 (Fig. 12c) are compared to the climate-only simulations (Simulation 1, Fig. 12b), our results suggest that changes in the meteorological fields are the main driver of DM8O enhancement in Simulations 2 and 3 (Fig. 12c and d) across the domain. Even though BVOC emissions are higher in Simulation 2 relative to Simulation 1, Simulation 2 resulted in 2-4 ppb lower DM8O in the Southeast. This decrease is associated with a reduction in $\mathrm{NO}_{x}$ concentrations (Fig. 14a). This decrease in $\mathrm{NO}_{x}$ suggests that the effect of sequestration of $\mathrm{NO}_{x}$ by the biogenic VOCs as organic nitrates $\left(\mathrm{RNO}_{3}\right)$ is predominant over the effect of recycling of $\mathrm{NO}_{x}$ considered in SAPRC99, which lumps all non-peroxyacetyl (non-PAN) organic nitrates as one compound that has a $\mathrm{NO}_{x}$ recycling efficiency of about $30 \%$. The simulated reduction in ozone is consistent with the results of Xie et al. (2013), who reported increases in $\mathrm{NO}_{x}$ and ozone in the Southeast when sequestration by isoprene nitrates was reduced relative to the base SAPRC-07T mechanism that has the same $\mathrm{RNO}_{3}$ treatment as SAPRC-99. Evidence of the predominant effect of sequestration over the recycling of $\mathrm{NO}_{x}$ in the eastern US is seen in Fig. 14, which shows an increase in $\mathrm{RNO}_{3}$ and reduction in the $\mathrm{NO}_{x}$ con- 
centrations in most of the eastern US for Simulation 2 relative to Simulation 1. When land use changes are included along with biogenic emissions, the increase in BVOC emissions is projected to be less while $\mathrm{NO}$ emission is projected to increase in areas where natural vegetation is converted to cropland. This combination leads to higher DM8O in Simulation 3 than Simulation 2 (Table 2, Fig. 12d).

\subsubsection{Contributions from combined global change to future changes in DM8O concentrations}

When the combined global changes are considered (Simulation 6), DM8O is projected to increase in all regions, except along the western coastlines. Increases of DM8O between 1 to $3 \mathrm{ppb}$ in the Northwest, Southwest and Northeast regions are shown along with a local increase of 1 to $6 \mathrm{ppb}$ in parts of the South, Midwest and Central regions (Fig. 12g). The increase in DM8O is mostly due to an increase in global emissions of ozone precursors from the semi-hemispheric domain, which contributes to an increase of 2-6 ppb under current climate conditions (Fig. 12f). The other contributing factors to increasing DM8O are a combination of meteorological changes (Fig. 12b) and higher BVOC emissions (with current and future land use; Fig. 12c, d). Reductions in DM8O in the urban areas resulted generally from reductions in ozone precursors from regional anthropogenic sources (Fig. 12e). However, in the western regions, lower DM8O are the result of a combination of favorable meteorological conditions (e.g., reduction in temperature and solar radiation reaching the ground) and reductions in regional ozone precursors.

\subsection{Effects of global changes upon $\mathrm{PM}_{2.5}$ concentrations}

Results for how the various global changes affect $\mathrm{PM}_{2.5}$ concentrations and composition are summarized in Tables 3-5 and Fig. 13. Overall, projected increase in US anthropogenic emissions have the largest impact on $\mathrm{PM}_{2.5}$, leading to an increase in concentrations in all regions. Changes in global emissions do not have a significant impact on $\mathrm{PM}_{2.5}$ concentrations, while changes in the climate and biogenic emissions can lead to both increases and decreases in $\mathrm{PM}_{2.5}$ depending on the region.

\subsubsection{Contribution to $\mathbf{P M}_{2.5}$ concentrations from changes in global and regional anthropogenic emissions}

The results from this study are similar to those reported by Avise et al. (2009), who predicted a change in $\mathrm{PM}_{2.5}$ of less than $1 \mu \mathrm{g} \mathrm{m}^{-3}$ as a result of changes in future chemical boundary conditions. In our simulation, the highest increase in $\mathrm{PM}_{2.5}$ concentrations is found in the South region $(<1 \%)$. This increase in the South region is indicative of the effects of increased emissions from Mexico (Fig. 13f).
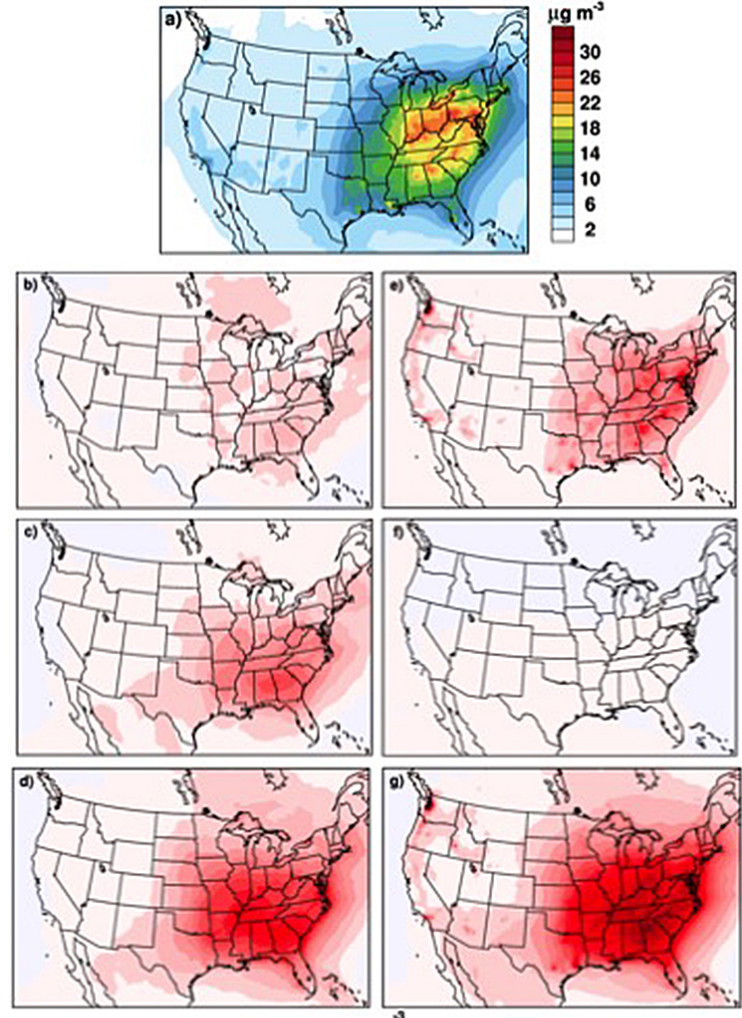

$\mu \mathrm{g} \mathrm{m}$

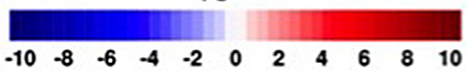

Figure 13. (a) Current decade base case $\mathrm{PM}_{2.5}$ average concentrations for five summers in the 2000s; and spatial distribution and regional effect on $\mathrm{PM}_{2.5}$ due to (b) changes in meteorology (Simulation 1-Simulation 0); (c) changes in meteorology and biogenic emissions (Simulation 2-Simulation 0); (d) changes in meteorology, biogenic emissions, and land use (Simulation 3-Simulation 0 ); (e) changes in US anthropogenic emissions (Simulation 4 Simulation 0); (f) changes in global anthropogenic emissions (Simulation 5-Simulation 0); and (g) all the changes above combined (Simulation 6-Simulation 0).

When the chemical composition is analyzed, Table 3 shows an increase in aerosol nitrate $\left(\mathrm{NO}_{3}^{-}\right)$in nearly all regions except for the South; these increases are less than $0.1 \mu \mathrm{g} \mathrm{m}^{-3}$, similar to the results of Avise et al. (2009). In our simulation, increases between 3 and $8 \%$ in $\mathrm{SO}_{4}^{2}$ and $\mathrm{NH}_{4}^{+}$in the Southwest, Central and South regions are mostly a result of increase in emissions of $\mathrm{SO}_{2}$ and $\mathrm{NH}_{3}$ from Mexico. Similarly, Avise et al. (2009) showed higher future concentrations (by 7 to $25 \%$ ) of $\mathrm{SO}_{4}^{2-}$ for the same regions resulting from higher global $\mathrm{SO}_{2}$ emissions. In our simulations, changes in global anthropogenic emissions cause reductions in SOA in the Southwest, Central and South regions and increases in the Northwest, Midwest, Southeast and Northeast regions (Table 4); the simulated changes in SOA are very small $(<1.3 \%$ and $<0.05 \mu \mathrm{g} \mathrm{m}^{-3}$ ) and the variation may be due to small differences in modeled $\mathrm{OH}$ radical concentrations. 
Table 3. Percent change in the aerosol $\mathrm{NH}_{4}^{+}, \mathrm{SO}_{4}^{2-}$ and $\mathrm{NO}_{3}^{-}$between each future scenario and the current decade base case. The corresponding simulation number for each sensitivity simulation is shown in parenthesis.

\begin{tabular}{|c|c|c|c|c|c|c|}
\hline Region & $\begin{array}{c}\text { Climate } \\
\text { (1) }\end{array}$ & $\begin{array}{l}\text { Climate } \\
\& \text { BVOC } \\
\text { (2) }\end{array}$ & $\begin{array}{l}\text { Climate, } \\
\text { BVOC, } \\
\text { land } \\
\text { use (3) }\end{array}$ & $\begin{array}{c}\text { US } \\
\text { anthropogenic } \\
\text { emissions } \\
\text { (4) }\end{array}$ & $\begin{array}{c}\text { Boundary } \\
\text { conditions } \\
(5)\end{array}$ & $\begin{array}{c}\text { Combined } \\
\text { (6) }\end{array}$ \\
\hline \multicolumn{7}{|c|}{$\mathrm{NH}_{4}^{+}$} \\
\hline Northwest & 15.7 & -0.6 & -0.9 & 12.8 & -0.2 & 12.2 \\
\hline Southwest & 3.4 & -8.8 & -7.9 & 4.2 & 8.2 & 4.8 \\
\hline Central & 12.5 & 2.1 & 2.7 & 6.9 & 3.3 & 14.8 \\
\hline South & 9.1 & 4.3 & 5.8 & 7.5 & 4.8 & 22.9 \\
\hline Midwest & 5.1 & 0.6 & 3.3 & 12.2 & 0.4 & 18.1 \\
\hline Northeast & 1.8 & -5.0 & -4.2 & 17.5 & -0.3 & 12.7 \\
\hline Southeast & 10.0 & 5.0 & 4.8 & 12.4 & 0.5 & 21.3 \\
\hline \multicolumn{7}{|c|}{$\mathrm{SO}_{4}^{2-}$} \\
\hline Northwest & 10.0 & -5.4 & -5.3 & 6.3 & 0.9 & 1.6 \\
\hline Southwest & 5.4 & -4.6 & -4.0 & 0.7 & 6.2 & 2.8 \\
\hline Central & 10.9 & 1.5 & 2.0 & 3.4 & 3.2 & 10.1 \\
\hline South & 7.3 & 3.7 & 4.7 & 1.5 & 4.8 & 14.5 \\
\hline Midwest & 7.2 & 1.8 & 4.1 & 2.7 & 0.4 & 10.9 \\
\hline Northeast & 3.5 & -4.0 & -3.2 & 3.2 & -0.2 & 2.3 \\
\hline Southeast & 8.8 & 3.5 & 2.9 & 1.9 & 0.8 & 9.3 \\
\hline \multicolumn{7}{|c|}{$\mathrm{NO}_{3}^{-}$} \\
\hline Northwest & -0.3 & 2.3 & 0.9 & 20.3 & 6.4 & 27.4 \\
\hline Southwest & -10.1 & -8.0 & -7.3 & 11.8 & 8.2 & 12.7 \\
\hline Central & -34.4 & -17.1 & -12.0 & 87.6 & 2.6 & 68.4 \\
\hline South & -7.0 & -18.7 & -11.5 & 38.5 & -2.0 & 17.0 \\
\hline Midwest & -38.4 & -31.1 & -23.6 & 96.6 & 2.6 & 56.4 \\
\hline Northeast & -43.9 & -43.2 & -42.1 & 74.0 & 2.0 & 4.8 \\
\hline Southeast & -29.4 & -28.7 & -28.7 & 54.6 & 7.5 & 19.6 \\
\hline
\end{tabular}

In the US, reductions in regional $\mathrm{SO}_{2}$ and $\mathrm{NO}_{x}$ emissions from regulatory curtailment on electricity generation are offset by the projected increase in emissions of $\mathrm{PM}_{2.5}$ and $\mathrm{NH}_{3}$ from other sources, thus resulting in an overall increase in $\mathrm{PM}_{2.5}$ concentrations between 1 and $4 \mu \mathrm{g} \mathrm{m}^{-3}$ across CONUS. Similarly, Avise et al. (2009) predicted an average increase of $3 \mu \mathrm{g} \mathrm{m}^{-3}$ across the domain but as a result of increasing $\mathrm{NO}_{x}$ and $\mathrm{SO}_{2}$ from anthropogenic sources. The greatest increase, between 2 and $4 \mu \mathrm{g} \mathrm{m}^{-3}$, is found in the urban areas across the Northwest, Northeast, Midwest and Southeast region (Fig. 13e) as a result of increase in primary emissions of $\mathrm{PM}_{2.5}$. Similarly, Trail et al. (2015) find an increase in $\mathrm{PM}_{2.5}$ concentrations between 1 and $2 \mu \mathrm{g} \mathrm{m}^{-3}$ as a result of a scenario that consider changes in fuel use. In contrast, Tagaris et al. (2007) predicted a decrease of $23 \%$ as a result of decreasing emissions. Increase in SOA concentrations resulted from higher emissions of NMVOC and an increase in primary organic aerosol from anthropogenic sources in the US (Table 4).
In terms of the inorganic $\mathrm{PM}_{2.5}$ components, reductions in $\mathrm{SO}_{2}$ and $\mathrm{NO}_{x}$ emissions in the US are offset by higher emissions of primary sulfate and nitrate and ammonia, leading to an increase in both sulfate and ammonium. Compared to Tagaris et al. (2007), our investigation shows no reduction in sulfate concentrations as a result of smaller reduction in $\mathrm{SO}_{2}$ emissions from anthropogenic sources. Furthermore, similar to Shimadera et al. (2014) the increase in nitrate concentrations in the form of ammonium nitrate is highly dependent on the increase in $\mathrm{NH}_{3}$ emissions and less sensitive to changes in emissions of $\mathrm{NO}_{x}$.

\subsubsection{Contribution to $\mathbf{P M}_{2.5}$ concentrations from global climate change alone}

Despite the effect of precipitation on PM loading, as it washes out the precursors and the existing PM from the atmosphere (Seinfeld and Pandis, 2006), the effect of climate change alone (with no change to biogenic emissions) on total $\mathrm{PM}_{2.5}$ concentrations over land is a change of less than 

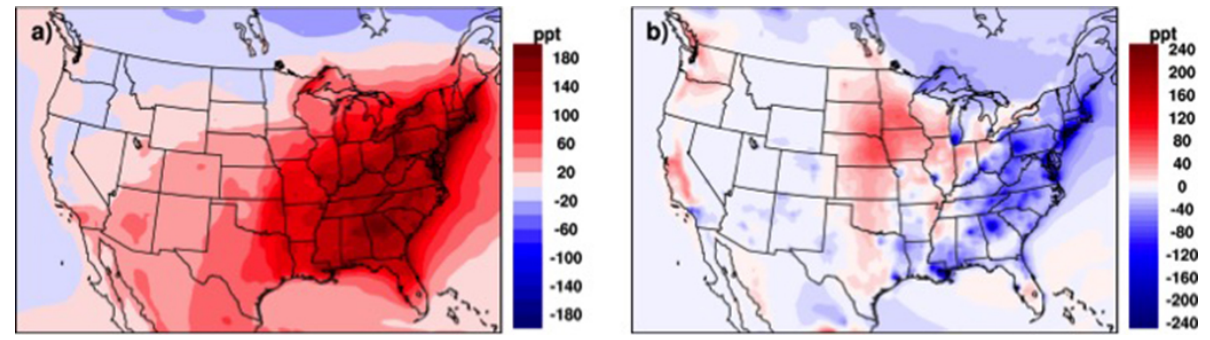

Figure 14. Differences in (a) $\mathrm{RNO}_{3}$ and (b) $\mathrm{NO}_{x}$ concentrations between Simulation 2 and Simulation 1.

$1 \mu \mathrm{g} \mathrm{m}^{-3}$ (Fig. 13b). However, the change in $\mathrm{PM}_{2.5}$ composition due to climate change is highly variable and depends on changes in temperature, relative humidity and precipitation. Increases in reaction rate constants of $\mathrm{SO}_{2}$ and higher oxidant concentrations from increased temperature and solar insolation lead to an increase in aerosol sulfate formed (Dawson et al., 2007). Relative humidity and temperature affect the thermodynamic equilibrium of $\mathrm{SO}_{4}^{2-}-\mathrm{NH}_{4}^{+}-\mathrm{NO}_{3}^{-}$, especially the partitioning of $\mathrm{HNO}_{3}$ between the gas and particulate phases.

For all regions, sulfate concentrations are predicted to increase by $3-10 \%$. Except for the Northwest regions, this change in concentrations is consistent with decreased precipitation, which reduces wet deposition, and increases in temperature and solar insolation, which increase radical production rates and increase the oxidation of $\mathrm{SO}_{2}$ to produce aerosol sulfate. The same increase in temperature leads to nitrate being more volatile and thus decreases aerosol nitrate concentrations in regions where sulfate concentrations are predicted to increase. For the same regions where sulfate is projected to increase, higher concentrations of radicals also lead to higher oxidation of VOC, thus increasing SOA concentrations in the same regions.

While increasing precipitation is generally associated with decreasing $\mathrm{PM}_{2.5}$, results here for the Northwest region showed an increase in $\mathrm{PM}_{2.5}$ despite an increase in precipitation (Fig. 13b). This suggests the effects of slightly colder temperature and higher relative humidity in this region, leading to an enhanced formation of ammonium nitrate (Table 3). Furthermore, the increase in relative humidity in the Northwest and the coastal areas of the Southwest regions leads to the increase in production of sulfate aerosol via aqueous reaction (Luo et al., 2011). Higher concentrations of ammonium nitrate and higher concentrations of SOA (Table 4) indicate increased aerosol formation dominate over the effect of precipitation.

\subsubsection{Contribution to $\mathbf{P M}_{2.5}$ concentrations from changes in biogenic emissions and future land use}

Simulations that consider projected climate change as well as the associated change in biogenic emissions (Simulation 2) show an increase in $\mathrm{PM}_{2.5}$ between 0.5 and $3 \mu \mathrm{g} \mathrm{m}^{-3}$; these changes are mainly reflected in areas with high biogenic sources (Fig. 13c). When the effects of future land use are considered (Simulation 3), an increase in the geographical extent of $\mathrm{PM}_{2.5}$ is observed in comparison to the climate and biogenic emissions case, and higher increases (up to $6 \mu \mathrm{g} \mathrm{m}^{-3}$ ) of $\mathrm{PM}_{2.5}$ are predicted in parts of the South, Southeast, Midwest and Northeast regions (Fig. 13d). This is primarily due to the increase in emissions of sesquiterpenes (not shown) and monoterpenes (Fig. 11b), leading to more SOA being formed.

In terms of the inorganic components of $\mathrm{PM}_{2.5}$, the effect of climate change is still the predominant factor for the change in sulfate concentrations for the Central, South, Midwest and Southeast regions (Table 3). The smaller increase or absolute reduction in sulfate in comparison to the climateonly case is due to the competition between $\mathrm{BVOC}$ and $\mathrm{SO}_{2}$ for the availability of $\mathrm{OH}$, which is an oxidant for both. Additionally, a smaller decrease in $\mathrm{NO}_{3}^{-}$in most of the domain and increase in the Northwest is predicted due to changes in the availability of $\mathrm{OH}$ as a result of the changes in emissions of BVOC and soil NO. The increase in availability of $\mathrm{OH}$ and increase in soil $\mathrm{NO}$ emissions lead to a higher formation of ammonium nitrate in Simulations 2 and 3 than in Simulation 1.

SOA concentrations are predicted to increase as a result of higher emissions of BVOC across the domain (Table 4). Furthermore, when climate change and biogenic emissions are combined with future land use, concentrations of SOA are predicted to increase up to $121 \%$ in the Central region and up to $188 \%$ in the Southeast due to increased biogenic monoterpene and sesquiterpene emissions (not shown).

\subsubsection{Changes in precursors and $\mathbf{P M}_{2.5}$ concentrations from the combined global changes}

Table 5 shows the summary of changes to $\mathrm{PM}_{2.5}$ for all Simulations. The differences in $\mathrm{PM}_{2.5}$ between the future decade and current decade base case are greater in the eastern half of the US compared to the western half. In the eastern half of the US, the largest increases in $\mathrm{PM}_{2.5}$ occur in the Southeast. Our results show that the 2 to $10 \mu \mathrm{g} \mathrm{m}^{-3}$ increase in $\mathrm{PM}_{2.5}$ in the Southeast region is dominated by higher concentrations of SOA due to increased biogenic emissions as a result 
Table 4. Percent change of SOA between each future scenario and the current decade base case. The corresponding simulation number for each sensitivity simulation is shown in parenthesis,

\begin{tabular}{lcccccc}
\hline Region & $\begin{array}{c}\text { Climate } \\
(1)\end{array}$ & $\begin{array}{c}\text { Climate } \\
\text { \& BVOC } \\
(2)\end{array}$ & $\begin{array}{c}\text { Climate } \\
\text { BVOC } \\
\text { \& land } \\
\text { use (3) }\end{array}$ & $\begin{array}{c}\text { US } \\
\text { anthropogenic } \\
\text { emissions } \\
(4)\end{array}$ & $\begin{array}{c}\text { Boundary } \\
\text { conditions } \\
(5)\end{array}$ & $\begin{array}{c}\text { Combined } \\
(6)\end{array}$ \\
\hline \multicolumn{7}{c}{ SOA } \\
Northwest & 11.6 & 17.5 & 40.7 & 17.4 & 1.3 & 61.1 \\
Southwest & 2.2 & 20.3 & 31.9 & 10.2 & -0.2 & 41.0 \\
Central & 16.2 & 43.9 & 118.6 & 7.1 & -0.2 & 126.4 \\
South & 4.7 & 57.0 & 113.2 & 7.4 & -0.4 & 121.3 \\
Midwest & 16.0 & 48.6 & 121.2 & 7.9 & 0.1 & 131.0 \\
Northeast & 17.9 & 59.5 & 108.8 & 9.8 & 0.2 & 119.1 \\
Southeast & 14.2 & 73.2 & 135.1 & 8.1 & 0.3 & 143.5 \\
\hline
\end{tabular}

Table 5. Percent change of $\mathrm{PM}_{2.5}$ between each future scenario and the current decade base case. The corresponding simulation number is shown is parenthesis.

\begin{tabular}{lcccccc}
\hline Region & $\begin{array}{c}\text { Climate } \\
(1)\end{array}$ & $\begin{array}{c}\text { Climate } \\
\text { \& BVOC } \\
(2)\end{array}$ & $\begin{array}{c}\text { Climate, } \\
\text { BVOC, } \\
\text { land } \\
\text { use (3) }\end{array}$ & $\begin{array}{c}\text { US } \\
\text { anthropogenic } \\
\text { emissions } \\
(4)\end{array}$ & $\begin{array}{c}\text { Boundary } \\
\text { conditions } \\
(5)\end{array}$ & $\begin{array}{c}\text { Combined } \\
(6)\end{array}$ \\
\hline \multicolumn{7}{c}{$\mathrm{PM}_{2.5}$} \\
\hline Northwest & 7.0 & 2.1 & 7.3 & 43.2 & -0.8 & 51.7 \\
Southwest & 3.3 & 3.3 & 7.1 & 20.7 & 0.7 & 27.8 \\
Central & 10.5 & 12.6 & 31.0 & 14.5 & 0.0 & 46.5 \\
South & 5.4 & 21.3 & 40.5 & 17.6 & 1.0 & 60.8 \\
Midwest & 7.8 & 15.2 & 37.6 & 22.4 & 0.1 & 61.2 \\
Northeast & 7.8 & 16.0 & 30.4 & 28.5 & 0.0 & 58.3 \\
Southeast & 10.6 & 29.8 & 52.4 & 24.3 & 0.4 & 78.5 \\
\hline
\end{tabular}

of climate change (Fig. 13c), changes in land use (Fig. 13d; Table 4) and increase in anthropogenic emissions (Fig. 13e). Table 5 indicates that the combination of climate change, biogenic emissions and land use, and increase in anthropogenic emissions increases the concentrations of $\mathrm{PM}_{2.5}$ between 27 and $78 \%$ depending on the region.

\section{Conclusions}

We have investigated the individual and combined contributions of factors that impact US air quality by dynamically downscaling future climate projections using the WRF model and using the regional chemical transport model CMAQ version 4.7.1. Decreases in future US anthropogenic ozone precursor emissions are the only consistently beneficial influence that improves the air quality in the US and updated assumptions to generate scenarios of future US anthropogenic emissions may show even more positive influence. However that positive influence is offset by (1) increasing global emissions and changes in long-range transport, which have a negative impact on air quality across the domain; (2) climate changes (namely, increased temperatures and solar radiation), which increase ozone concentrations in the Central, South, Midwest, Northeast and Southeast regions of the domain; and (3) increases in US BVOC emissions, which also increase ozone concentrations in regions with high biogenic emissions such as the South, Midwest, Northeast and Southeast.

In the case of the overall concentrations of $\mathrm{PM}_{2.5}$, our results indicate that the effects of increasing biogenic emissions in addition to increased primary PM from anthropogenic sources have an overall negative impact on air quality by increasing $\mathrm{PM}_{2.5}$ concentrations between 27 and $78 \%$. In terms of the $\mathrm{PM}_{2.5}$ composition, we show a regionally dependent mixture of inorganic aerosols and SOA. For the case of the Southeast, our findings indicate that increases in BVOC may result in higher concentrations of $\mathrm{PM}_{2.5}$. This effect extends to the Midwest and Northeast regions due to changes in land use. Furthermore, meteorological changes or regulatory curtailment, as incorporated in these simulations do not offset the increasing concentrations of primary PM 
and BVOC. In addition, synergistic effects of changes in meteorological parameters and changes in emission may shift the composition of the inorganic fraction of $\mathrm{PM}_{2.5}$ in the US. The synergistic effects of increase of sulfate and SOA in the urban areas of the coastal regions of the Northwest and Southwest lead to an increase in $\mathrm{PM}_{2.5}$ in those regions, offsetting decreases due to increased precipitation and temperature, and reduced primary anthropogenic emissions of $\mathrm{SO}_{2}$ and $\mathrm{NO}_{x}$.

In conclusion, the results of this study suggest that the efforts to improve air quality through low emission technologies and public policy directed to the electricity generation sector may not have a major effect, if future emissions from other sectors are allowed to increase. In addition, higher global anthropogenic emissions, a warmer future world and the effects of these changes on emissions from biogenic sources may increasingly undermine all regulatory efforts. Consequently, additional measures may be necessary to improve air quality in the US.

Much of the modeling components used for this research carry different levels of complexity and have reached diverse stages of development; thus, subsequent research intended to assess the effect of climate change and future regional emissions upon air quality would benefit from newer versions of the emission inventories (e.g., 2011), updated assumptions on the US emission projections (e.g., New versions of MARKAL with the use of the ESP 2.0 methodology), newer versions of MEGAN that take into account the isoprene emission suppression due to $\mathrm{CO}_{2}$ concentrations and more realistic estimates of land use change, and the inclusion of emissions from wildfires and the consequent effect upon air quality.

Acknowledgements. This work was supported by the US Environmental Protection Agency Science To Achieve Results grants RD 83336901-0 and 838309621-0. This paper has been cleared by the EPA's administrative review process and approved for publication. The views expressed in this paper are those of the authors and do not necessarily reflect the views or policies of the US Environmental Protection Agency.

Edited by: A. Carlton

\section{References}

Alcamo, J.: IMAGE 2.0: Integrated Modeling Of Global Climate Change, Kluwer Academic, Dordrecht, 1994.

Ambrose, J. L., Reidmiller, D. R., and Jaffe, D. A.: Causes of high $\mathrm{O}_{3}$ in the lower free troposphere over the Pacific Northwest as observed at the Mt. Bachelor Observatory, Atmos. Environ., 45, 5302-5315, 2011.

Andersson, C. and Engardt, M.: European ozone in a future climate: Importance of changes in dry deposition and isoprene emissions, J. Geophys. R., 115, D02303, doi:10.1029/2008JD011690, 2010.
Appel, K. W., Chemel, C., Roselle, S. J., Francis, X. V., Hu, R. M., Sokhi, R. S., Rao, S. T., and Galmarini, S.: Examination of the Community Multiscale Air Quality (CMAQ) model performance over the North American and European domains, Atmos. Environ., 53, 142-155, 2012.

Avise, J., Chen, J., Lamb, B., Wiedinmyer, C., Guenther, A., Salathé, E., and Mass, C.: Attribution of projected changes in summertime US ozone and $\mathrm{PM}_{2.5}$ concentrations to global changes, Atmos. Chem. Phys., 9, 1111-1124, doi:10.5194/acp9-1111-2009, 2009.

Avise, J., Abraham, R. G., Chung, S. H., Chen, J., Lamb, B., Salathé, E. P., Zhang, Y., Nolte, C. G., Loughlin, D. H., and Guenther, A.: Evaluating the effects of climate change on summertime ozone using a relative response factor approach for policymakers, J. Air Waste. Manage., 62, 1061-1074, 2012.

Bond, T. C., Streets, D. G., Yarber, K. F., Nelson, S. M., Woo, J. H., and Klimont, Z.: A technology-based global inventory of black and organic carbon emissions from combustion, J. Geophys. Res., 109, D14203, doi:10.1029/2003JD003697, 2004.

Boylan, J. W. and Russell, A. G.: PM and light extinction model performance metrics, goals, and criteria for three-dimensional air quality models, Atmos. Environ., 40, 4946-4959, 2006.

Byun, D. and Schere, K. L.: Review of the governing equations, computational algorithms, and other components of the Models3 Community Multiscale Air Quality (CMAQ) modeling system, Appl. Mech. Rev., 59, 51-77, doi:10.1115/1.2128636, 2006.

Carlton, A. G., Bhave, P. V., Napelenok, S. L., Edney, E. O., Sarwar, G., Pinder, R. W., Pouliot, G. A., and Houyoux, M.: Model representation of secondary organic aerosol in CMAQv4. 7, Environ. Sci. Technol., 44, 8553-8560, 2010.

Carter, W. P. L.: A detailed mechanism for the gas-phase atmospheric reactions of organic compounds, Atmos. Environ., 24, 481-518, 1990.

Carter, W. P. L.: Documentation of the SAPRC-99 Chemical Mechanism for VOC Reactivity Assessment, Report to the California Air Resources Board, available at: http://www.cert.ucr.edu/ $\sim$ carter/absts.htm\#saprc99, last access: 5 August 2009.

Chen, J., Avise, J., Guenther, A., Wiedinmyer, C., Salathe, E., Jackson, R. B., and Lamb, B.: Future land use and land cover influences on regional biogenic emissions and air quality in the United States, Atmos. Environ., 43, 5771-5780, doi:10.1016/j.atmosenv.2009.08.015, 2009a.

Chen, J., Avise, J., Lamb, B., Salathé, E., Mass, C., Guenther, A., Wiedinmyer, C., Lamarque, J.-F., O’Neill, S., McKenzie, D., and Larkin, N.: The effects of global changes upon regional ozone pollution in the United States, Atmos. Chem. Phys., 9, 11251141, doi:10.5194/acp-9-1125-2009, 2009b.

Christensen, J. H., Hewitson, B., Busuioc, A., Chen, A., Gao, X., Held, I., Jones, R., Kolli, R. K., Kwon, W.-T., Laprise, R., Magaña Rueda, V., Mearns, L., Menéndez, C. G., Räisänen, J., Rinke, A., Sarr, A., and Whetton, P.: Regional Climate Projections, in: Climate Change: The Physical Science Basis. Contribution of Working Group I to the Fourth Assessment Report of the Intergovernmental Panel on Climate Change, edited by: Solomon, S., Qin, D., Manning, M., Chen, Z., Marquis, M., Averyt, K. B., Tignor, M., and Miller, H. L., Cambridge University Press, Cambridge, UK and New York, NY, USA, 2007.

Cooper, O. R., Parrish, D. D., Stohl, A., Trainer, M., Nedelec, P., Thouret, V., Cammas, J. P., Oltmans, S. J., Johnson, B. J., Tara- 
sick, D., Leblanc, T., McDermid, I. S., Jaffe, D., Gao, R., Stith, J., Ryerson, T., Aikin, K., Campos, T., Weinheimer, A., and Avery, M. A.: Increasing springtime ozone mixing ratios in the free troposphere over western North America, Nature, 463, 344-348, doi:10.1038/nature08708, 2010.

Cooper, O. R., Gao, R.-S., Tarasick, D., Leblanc, T., and Sweeney, C.: Long-term ozone trends at rural ozone monitoring sites across the United States, 1990-2010, J. Geophys. Res., 117, D22307, doi:10.1029/2012JD018261, 2012.

Dadvand, P., Parker, J., Bell, M. L., Bonzini, M., Brauer, M., Darrow, L. A., Gehring, U., Glinianaia, S. V., Gouveia, N., Ha, E., Leem, J. H., Van den Hooven, E. H., Jalaludin, B., Jesdale, B. M., Lepeule, J., Morello-Frosch, R., Morgan, G. G., Pesatori, A. C., Pierik, F. H., Pless-Mulloli, T., Rich, D. Q., Sathyanarayana, S., Seo, J., Slama, R., Strickland, M., Tamburic, L., Wartenberg, D., Nieuwenhuijsen, M. J., and Woodruff, T. J.: Maternal Exposure to Particulate Air Pollution and Term Birth Weight: A MultiCountry Evaluation of Effect and Heterogeneity, Environ. Health Persp., 121, 267-373, doi:10.1289/ehp.1205575, 2012.

Dawson, J. P., Adams, P. J., and Pandis, S. N.: Sensitivity of $\mathrm{PM}_{2.5}$ to climate in the Eastern US: a modeling case study, Atmos. Chem. Phys., 7, 4295-4309, doi:10.5194/acp-7-4295-2007, 2007.

Dawson, J. P., Racherla, P. N., Lynn, B. H., Adams, P. J., and Pandis, S. N.: Impacts of climate change on regional and urban air quality in the eastern United States: Role of meteorology, J. Geophys. Res.-Atmos., 114, D05308, doi:10.1029/2008JD009849, 2009.

Dawson, J. P., Bloomer, B. J., Winner, D. A., and Weaver, C. P.: Understanding the meteorological drivers of U.S. particulate matter concentrations in a changing climate, B. Am. Meteorol. Soc., 95, 521-532, doi:10.1175/BAMS-D-12-00181.1, 2013.

Day, M. C. and Pandis, S. N.: Effects of a changing climate on summertime fine particulate matter levels in the eastern U.S.: AIR QUALITY IN A CHANGING CLIMATE, J. Geophys. Res., 120, 5706-5720, doi:10.1002/2014JD022889, 2015.

Dulière, V., Zhang, Y., and Salathé Jr., E. P.: Extreme Precipitation and Temperature over the U.S. Pacific Northwest: A Comparison between Observations, Reanalysis Data, and Regional Models, J. Climate, 24, 1950-1964, doi:10.1175/2010JCLI3224.1, 2011.

Dulière, V., Zhang, Y., and Salathé Jr., E. P.: Changes in twentiethcentury extreme temperature and precipitation over the western United States based on observations and regional climate model simulations, J. Climate, 26, 8556-8575, doi:10.1175/JCLI-D-12$00818.1,2013$.

Fiore, A. M., West, J. J., Horowitz, L. W., Naik, V., and Schwarzkopf, M. D.: Characterizing the tropospheric ozone response to methane emission controls and the benefits to climate and air quality, J. Geophys. Res., 113, D08307, doi:10.1029/2007JD009162, 2008.

Foley, K. M., Roselle, S. J., Appel, K. W., Bhave, P. V., Pleim, J. E., Otte, T. L., Mathur, R., Sarwar, G., Young, J. O., Gilliam, R. C., Nolte, C. G., Kelly, J. T., Gilliland, A. B., and Bash, J. O.: Incremental testing of the Community Multiscale Air Quality (CMAQ) modeling system version 4.7, Geosci. Model Dev., 3, 205-226, doi:10.5194/gmd-3-205-2010, 2010.

Forkel, R. and Knoche, R.: Regional climate change and its impact on photooxidant concentrations in southern Germany: Simulations with a coupled regional climate-chemistry model, J. Geophys. Res., 111, D12302, doi:10.1029/2005JD006748, 2006.
Giorgi, F. and Meleux, F.: Modelling the regional effects of climate change on air quality, C. R. Geosci., 339, 721-733, doi:10.1016/j.crte.2007.08.006, 2007.

Granier, C., Lamarque, J. F., Mieville, A., Muller, J. F., Olivier, J., Orlando, J., Peters, J., Petron, G., Tyndall, G., and Wallens, S.: POET a database of surface emissions of ozone precursors, available at: http://www.aero.jussieu.fr/projet/ACCENT/POET. php (last access: 10 October 2007), 2005.

Grell, G. A., Dudhia, J., and Stauffer, D. R.: A Description of the Fifth-Generation Penn tate/NCAR Mesoscale Model (MM5), National Center for Atmospheric Research, Boulder, CO, USA, NCAR/TN-398+STR., 122 pp., 1994.

Guenther, A.: Biological and Chemical Diversity of Biogenic Volatile Organic Emissions into the Atmosphere, Atmos. Sci., 2013, 786290, doi:10.1155/2013/786290, 2013.

Guenther, A., Karl, T., Harley, P., Wiedinmyer, C., Palmer, P. I., and Geron, C.: Estimates of global terrestrial isoprene emissions using MEGAN (Model of Emissions of Gases and Aerosols from Nature), Atmos. Chem. Phys., 6, 3181-3210, doi:10.5194/acp-63181-2006, 2006.

Hanna, S. R., Russell, A. G., Wilkinson, J. G., Vukovich, J., and Hansen, D. A.: Monte Carlo estimation of uncertainties in BEIS3 emission outputs and their effects on uncertainties in chemical transport model predictions, J. Geophys. Res., 110, D01302, doi:10.1029/2004JD004986, 2005.

Heald, C. L., Wilkinson, M. J., Monson, R. K., Alo, C. A., Wang, G., and Guenther, A.: Response of isoprene emission to ambient $\mathrm{CO}_{2}$ changes and implications for global budgets, Global Change Biol., 15, 1127-1140, 2009.

Hogrefe, C., Lynn, B., Civerolo, K., Ku, J. Y., Rosenthal, J., Rosenzweig, C., Goldberg, R., Gaffin, S., Knowlton, K., and Kinney, P. L.: Simulating changes in regional air pollution over the eastern United States due to changes in global and regional climate and emissions, J. Geophys. Res., 109, D22301, doi:10.1029/2004JD004690, 2004.

Hogrefe, C., Isukapalli, S. S., Tang, X., Georgopoulos, P. G., He, S., Zalewsky, E. E., Hao, W., Ku, J.-Y., Key, T., and Sistla, G.: Impact of biogenic emission uncertainties on the simulated response of ozone and fine particulate patter to anthropogenic emission reductions, J. Air Waste Manage., 61, 92-108, doi:10.3155/10473289.61.1.92, 2011.

Horowitz, L. W.: Past, present, and future concentrations of tropospheric ozone and aerosols: Methodology, ozone evaluation, and sensitivity to aerosol wet removal, J. Geophys. Res., 111, D22211, doi:10.1029/2005JD006937, 2006.

Huang, H.-C., Liang, X.-Z., Kunkel, K. E., Caughey, M., and Williams, A.: Seasonal Simulation of Tropospheric Ozone over the Midwestern and Northeastern United States: An Application of a Coupled Regional Climate and Air Quality Modeling System, J. Appl. Meteorol. Clim., 46, 945-960, doi:10.1175/JAM2521.1, 2007.

Huang, H.-C., Lin, J., Tao, Z., Choi, H., Patten, K., Kunkel, K., Xu, M., Zhu, J., Liang, X.-Z., Williams, A., Caughey, M., Wuebbles, D. J., and Wang, J.: Impacts of long-range transport of global pollutants and precursor gases on U.S. air quality under future climatic conditions, J. Geophys. Res., 113, D19307, doi:10.1029/2007JD009469, 2008.

IPCC: Intergovernmental Panel on Climate Change and Intergovernmental Panel on Climate Change: Climate change 2007: the 
physical science basis: contribution of Working Group I to the Fourth Assessment Report of the Intergovernmental Panel on Climate Change, Cambridge University Press, Cambridge, New York, 2007.

Jacob, D. J. and Winner, D. A.: Effect of climate change on air quality, Atmos. Environ., 43, 51-63, doi:10.1016/j.atmosenv.2008.09.051, 2009.

Karl, T. R., Williams, J. C. N., Quinlan, F. T., and Boden, T. A.: United States Historical Climatology Network (HCN) Serial Temperature and Precipitation Data, Vol. 3404, Environmental Science Division Publication, Carbon Dioxide Information and Analysis Center, Oak Ridge National Laboratory, 389 pp., 1990

Kelly, J., Makar, P. A., and Plummer, D. A.: Projections of mid-century summer air-quality for North America: effects of changes in climate and precursor emissions, Atmos. Chem. Phys., 12, 5367-5390, doi:10.5194/acp-12-5367-2012, 2012.

Kunkel, K. E., Huang, H. C., Liang, X. Z., Lin, J. T., Wuebbles, D., Tao, Z., Williams, A., Caughey, M., Zhu, J., and Hayhoe, K.: Sensitivity of future ozone concentrations in the northeast USA to regional climate change, Mitigation Adapt, Strategies Global Change, 13, 597-606, 2007.

Langner, J., Bergstrom, R., and Foltescu, V.: Impact of climate change on surface ozone and deposition of sulphur and nitrogen in Europe, Atmos. Environ., 39, 1129-1141, doi:10.1016/j.atmosenv.2004.09.082, 2005.

Lelieveld, J. and Dentener, F.: What controls tropospheric ozone?, J. Geophys. Res., 105, 3531-3551, 2009.

Leung, L. R. and Gustafson, W. I.: Potential regional climate change and implications to US air quality, Geophys. Res. Lett., 32, L16711, doi:10.1029/2005GL022911, 2005.

Leung, L. R., Kuo, Y. H., and Tribbia, J.: Research needs and directions of regional climate modeling using WRF and CCSM, B. Am. Meteorol. Soc., 87, 1747-1751, 2006.

Liao, H., Chen, W. T., and Seinfeld, J. H.: Role of climate change in global predictions of future tropospheric ozone and aerosols, J. Geophys. Res., 111, D12304, doi:10.1029/2005JD006852, 2006.

Liang, X.-Z., Pan, J., Zhu, J., Kunkel, K. E., Wang, J. X. L., and Dai, A.: Regional climate model downscaling of the U.S. summer climate and future change, J. Geophys. Res., 111, D10108, doi:10.1029/2005JD006685, 2006.

Lin, J.-T., Patten, K. O., Hayhoe, K., Liang, X.-Z., and Wuebbles, D. J.: Effects of future climate and biogenic emissions changes on surface ozone over the United States and China, J. Appl. Meteorol. Clim., 47, 1888-1909, 2008.

Lin, M., Fiore, A. M., Horowitz, L. W., Cooper, O. R., Naik, V., Holloway, J., Johnson, B. J., Middlebrook, A. M., Oltmans, S. J., Pollack, I. B., Ryerson, T. B., Warner, J. X., Wiedinmyer, C., Wilson, J., and Wyman, B.: Transport of Asian ozone pollution into surface air over the western United States in spring, J. Geophys. Res., 117, D00V07, doi:10.1029/2011JD016961, 2012.

Loughlin, D. H., Benjey, W. G., and Nolte, C. G.: ESP v1.0: methodology for exploring emission impacts of future scenarios in the United States, Geosci. Model Dev., 4, 287-297, doi:10.5194/gmd-4-287-2011, 2011.

Loulou, R., Goldstein, G., and Noble, K.: Documentation for the MARKAL family of models. Energy Technology Systems Analysis Programme: Paris, France, available at: http://www.etsap. org/tools.htm (last access: 15 September 2011), 2004.
Luo, C., Wang, Y., Mueller, S., and Knipping, E.: Diagnosis of an underestimation of summertime sulfate using the Community Multiscale Air Quality model, Atmos. Environ., 45, 5119-5130, 2011.

Meleux, F., Solmon, F., and Giorgi, F.: Increase in summer European ozone amounts due to climate, Atmos. Environ., 41, doi:10.1016/j.atmosenv.2007.05.048, 7577-7587, 2007.

Nakicenovic, N., Nakicenovic, N., Alcamo, J., Davis, G., de Vries, B., Fenhann, J., Gaffin, S., Gregory, K., Grübler, A., Yong Jung, T., Kram, T., Lebre, La Rovere, E. L., Michaelis, L., Mori, S., Morita, T., Pepper, W., Pitcher, H., Price, L., Riahi, K., Roehrl, A., Rogner, H-H., Sankovski, A., Schlesinger, M., Shukla, P., Smith, S., Swart, R., van Rooijen, S., Victor, N., and Dadi, Z.: IPCC Special Report on Emissions Scenarios, Cambridge University Press, Cambridge, UK, 2000.

Neilson, R. P.: A Model for Predicting Continental-Scale Vegetation Distribution and Water Balance, Ecol. Appl., 5, 362-385, 1995.

Nolte, C. G., Gilliland, A. B., Hogrefe, C., and Mickley, L. J.: Linking global to regional models to assess future climate impacts on surface ozone levels in the United States, J. Geophys. Res., 113, D14307, doi:10.1029/2007JD008497, 2008.

Otte, T. L. and Pleim, J. E.: The Meteorology-Chemistry Interface Processor (MCIP) for the CMAQ modeling system: updates through MCIPv3.4.1, Geosci. Model Dev., 3, 243-256, doi:10.5194/gmd-3-243-2010, 2010.

Racherla, P. N. and Adams, P. J.: Sensitivity of global tropospheric ozone and fine particulate matter concentrations to climate change, J. Geophys. Res., 111, D24103, doi:10.1029/2005JD006939, 2006.

Racherla, P. N. and Adams, P. J.: The response of surface ozone to climate change over the Eastern United States, Atmos. Chem. Phys., 8, 871-885, doi:10.5194/acp-8-871-2008, 2008.

Raes, F., Liao, H., Chen, W. T., and Seinfeld, J. H.: Atmospheric chemistry-climate feedbacks, J. Geophys. Res., 115, D12121, doi:10.1029/2009JD013300, 2010.

Ramankutty, N. and Foley, J. A.: Characterizing patterns of global land use: An analysis of global croplands data, Global Biogeochem. Cy., 12, 667-685, 1998.

Ramankutty, N., Foley, J. A., Norman, J., and McSweeney, K.: The global distribution of cultivable lands: Current patterns and sensitivity to possible climate change, Global Ecol. Biogeogr., 11, 377-392, 2002.

Ravishankara, A. R., Dawson, J. P., and Winner, D. A.: New Directions: Adapting air quality management to climate change: A must for planning, Atmos. Environ., 50, 387-389, doi:10.1016/j.atmosenv.2011.12.048, 2012.

Roeckner, E., Bengtsson, L., Feichter, J., Lelieveld, J., and Rodhe, H.: Transient climate change simulations with a coupled atmosphere-ocean GCM including the tropospheric sulfur cycle, J. Climate, 3004-3032, 1999.

Roeckner, E., Bauml, G., Bonaventura, L., Brokopf, R., Esch, M., Giorgetta, M., Hagemann, S., Kirchner, I., Kornbleuh, L., Manzini, E., Rhodin, A., Schelse, U., Schulzweida, U., and Tomkins, A.: The atmospheric general circulation model ECHAM5, Part I: model description, Max-Planck Institute of Meteorology Report No. 349, Hamburg, Germany, 2003.

Rosenstiel, T. N., Potosnak, M. J., Griffin, K. L., Fall, R., and Monson, R. K.: Increased $\mathrm{CO}_{2}$ uncouples growth from isoprene emission in an agriforest ecosystem, Nature, 421, 256-259, 2003. 
Sakulyanontvittaya, T., Yarwood, G., and Guenther, A.: Improved biogenic emission inventories across the West - Final Report, ENVIRON International Corporation, Novato, California, 19 March, available at: http://www.wrapair2.org/pdf/WGA_ BiogEmisInv_FinalReport_March20_2012.pdf, 2013.

Sakulyanontvittaya, T., Duhl, T., Wiedinmyer, C., Helmig, D., Matsunaga, S., Potosnak, M., Milford, J., and Guenther, A.: Monoterpene and sesquiterpene emission estimates for the United States, Environ. Sci. Technol., 42, 1623-1629, 2008

Salathé, E., Leung, L., Qian, Y., and Zhang, Y.: Regional climate model projections for the State of Washington, Climatic Change, 102, 51-75, 2010.

Seinfeld, J. H. and Pandis, S. N.: Atmospheric Chemistry and Physics: From air pollution to climate change, 2nd Edn., John Wiley and Sons, Inc, New Jersey, 2006.

Shay, C. L., Yeh, S., Decarolis, J., Loughlin, D. H., Gage, C. L., and Wright, E.: EPA U.S. National MARKAL Database: Database Documentation, US Environmental Protection Agency, Washington, DC, EPA/600/R-06/057, 2006.

Shimadera, H., Hayami, H., Chatani, S., Morino, Y., Mori, Y., Morikawa, T., Yamaji, K., and Ohara, T.: Sensitivity analyses of factors influencing CMAQ performance for fine particulate nitrate, J. Air Waste. Manage., 64, 374-387, doi:10.1080/10962247.2013.778919, 2014.

Spracklen, D. V., Mickley, L. J., Logan, J. A., Hudman, R. C., Yevich, R., Flannigan, M. D. and Westerling, A. L.: Impacts of climate change from 2000 to 2050 on wildfire activity and carbonaceous aerosol concentrations in the western United States, J. Geophys. Res., 114, D20301, doi:10.1029/2008JD010966, 2009.

Steiner, A. L., Tonse, S., Cohen, R. C., Goldstein, A. H., and Harley, R. A.: Influence of future climate and emissions on regional air quality in California, J. Geophys. Res., 111, D18303, doi:10.1029/2005JD006935, 2006.

Tagaris, E., Manomaiphiboon, K., Liao, K.-J., Leung, L. R., Woo, J.-H., He, S., Amar, P., and Russell, A. G.: Impacts of global climate change and emissions on regional ozone and fine particulate matter concentrations over the United States, J. Geophys. Res., 112, D14312, doi:10.1029/2006JD008262, 2007.

Tao, Z., Williams, A., Huang, H. C., Caughey, M., and Liang, X. Z.: Sensitivity of US surface ozone to future emissions and climate changes, Geophys. Res. lett., 34, L08811, doi:10.1029/2007GL029455, 2007.

Trail, M. A., Tsimpidi, A. P., Liu, P., Tsigaridis, K., Hu, Y., Rudokas, J. R., Miller, P. J., Nenes, A., and Russell, A. G.: Impacts of Potential $\mathrm{CO}_{2}$-Reduction Policies on Air Quality in the United States, Environ. Sci. Technol., 49, 5133-5141, doi:10.1021/acs.est.5b00473, 2015.

Unger, N., Shindal, D. T., Koch, D. M., Amann, M., Cofala, J., and Streets, D. G.: Influences of man-made emissions and climate changes in tropospheric ozone, methane and sulfate at 2030 from a broad range of possible futures, J. Geophys. Res., 111, D12313, doi:10.1029/2005JD006518, 2006.

US CFR (United States Code of Federal Regulations): 2017-2025 model year light-duty vehicle GHG and 904 CAFE standards: supplemental notice of intent, United States 905, Federal Register 76(153), 2011.

US Department of Energy: Energy Information Administration (US EIA), Annual Energy Outlook 2008 with Projections to 2030,
DOE/EIA-0383(2008), US Department of Energy, Washington, D.C., 2008.

US EPA (US Environmental Protection Agency): Quality assurance guidance document - Final quality assurance project plan: $\mathrm{PM}_{2.5}$ speciation trends network field sampling (EPA-454/R-01-001), US environmental protection agency, Office of air quality planning and standards, Research triangle park, NC, 2000.

US EPA (US Environmental Protection Agency): Clean Air Interstate Rule emissions inventory technical support document, US Environmental Protection Agency, Office of Air Quality Planning and Standards, Research Triangle Park, NC, available at: http://archive.epa.gov/airmarkets/programs/ cair/web/pdf/finaltech01.pdf (last access: March 2011), 2005.

US EPA (US Environmental Protection Agency: National Ambient Air Quality Standards for Ozone, Proposed Rule, Federal Register, 75, 2938-3052, 2010.

US EPA (US Environmental Protection Agency): Office of Research and Development, EPA US Nine Region MARKAL Database: Database Documentation, NTIS number forthcoming, Research Triangle Park, N.C., 2013.

Washington, W. M., Weatherly, J. W., Meehl, G. A., Semtner, A. J., Bettge, T. W., Craig, A. P., Strand, W. G., Arblaster, J., Wayland, V. B., James, R., and Zhang, Y.: Parallel Climate Model (PCM) control and transient simulations, Clim. Dynam., 16, 755-774, 2000.

Weaver, C. P., Cooter, E., Gilliam, R., Gilliland, A., Grambsch, A., Grano, D., Hemming, B., Hunt, S. W., Nolte, C., Winner, D. A., Liang, X.-Z., Zhu, J., Caughey, M., Kunkel, K., Lin, J.-T., Tao, Z., Williams, A., Wuebbles, D. J., Adams, P. J., Dawson, J. P., Amar, P., He, S., Avise, J., Chen, J., Cohen, R. C., Goldstein, A. H., Harley, R. A., Steiner, A. L., Tonse, S., Guenther, A., Lamarque, J.-F., Wiedinmyer, C., Gustafson, W. I., Leung, L. R., Hogrefe, C., Huang, H.-C., Jacob, D. J., Mickley, L. J., Wu, S., Kinney, P. L., Lamb, B., Larkin, N. K., McKenzie, D., Liao, K.-J., Manomaiphiboon, K., Russell, A. G., Tagaris, E., Lynn, B. H., Mass, C., Salathé, E., O’neill, S. M., Pandis, S. N., Racherla, P. N., Rosenzweig, C., and Woo, J.-H.: A Preliminary Synthesis of Modeled Climate Change Impacts on U.S. Regional Ozone Concentrations, B. Am. Meteorol. Soc., 90, 1843-1863, doi:10.1175/2009BAMS2568.1, 2009.

WHO (World Health Organization): Air quality guidelines for particulate matter, ozone, nitrogen dioxide and sulfur dioxide: Summary of risk assessment, Geneva, Switzerland, 2005.

WMO (World Meteorological Organization): Global Atmosphere Watch: WMO/iGAC Impacts of Megacities on Air Pollution and Climate, Geneva, Switzerland, 2012.

Wu, S., Mickley, L. J., Leibensperger, E. M., Jacob, D. J., Rind, D., and Streets, D. G.: Effects of 2000-2050 global change on ozone air quality in the United States, J. Geophys. Res., 113, D06302, doi:10.1029/2007JD008917, 2008a.

Wu, S., Mickley, L. J., Jacob, D. J., Rind, D., and Streets, D. G.: Effects of 2000-2050 changes in climate and emissions on global tropospheric ozone and the policy-relevant background ozone in the United States, J. Geophys. Res., 113, D18312, doi:10.1029/2007JD009639, 2008b.

Wuebbles, D. J., Lei, H., and Lin, J.: Intercontinental transport of aerosols and photochemical oxidants from Asia and its consequences, Environ. Pollut., 150, 65-84, 2007. 
Xie, Y., Paulot, F., Carter, W. P. L., Nolte, C. G., Luecken, D. J., Hutzell, W. T., Wennberg, P. O., Cohen, R. C., and Pinder, R. W.: Understanding the impact of recent advances in isoprene photooxidation on simulations of regional air quality, Atmos. Chem. Phys., 13, 8439-8455, doi:10.5194/acp-13-8439-2013, 2013.

Zhang, L., Jacob, D. J., Downey, N. V., Wood, D. A., Blewitt, D., Carouge, C. C., Van Donkelaar, A., Jones, D., Murray, L. T., and Wang, Y.: Improved estimate of the policyrelevant background ozone in the United States using the GEOS-Chem global model with $1 / 2$ times $2 / 3$ horizontal resolution over North America, Atmos. Environ., 45, 6769-6776, doi:10.1016/j.atmosenv.2011.07.054, 2011.

Zhang, Y., Dulière, V., and Salathé Jr., E. P.: Evaluation of WRF and HadRM mesoscale climate simulations over the United States Pacific Northwest, J. Climate, 22, 5511-5526, 2009.
Zhang, Y., Olsen, S. C., and Dubey, M. K.: WRF/Chem simulated springtime impact of rising Asian emissions on air quality over the U.S., Atmos. Environ., 44, 2799-2812, 2010.

Zhang, Y., Qian, Y., Dulière, V., Salathé Jr., E. P., and Leung, L. R.: ENSO anomalies over the Western United States: present and future patterns in regional climate simulations, Climatic Change, 110, 315-346, doi:10.1007/s10584-011-0088-7, 2012.

Zuidema, G., Born, G. J., Alcamo, J., and Kreileman, G. J. J.: Simulating changes in global land cover as affected by economic and climatic factors, Water Air Soil Poll., 76, 163-198, doi:10.1007/BF00478339, 1994. 